\title{
Some Selected Models from the Architectural Heritage in Germany during the Eighteenth and Nineteenth Centuries -"A Study from an Archaeological Point of View"
}

\author{
Ghadeer Dardier Afify Khalifa \\ Associate Professor - Islamic Department- Faculty of Archaeology- Fayoum University- Al- \\ Fayoum City, Main Building of Faculty of Archaeology \\ Postcode: 63514, Al-Fayoum Governorate, Egypt \\ E-Mail: gdk00@fayoum.edu.eg
}

\begin{abstract}
:
This study aims to discuss some selected models from the architectural heritage in Germany during the Eighteenth and Nineteenth Centuries and this will be through a study from an archaeological point of view. When looking for the architectural heritage in Germany during the Eighteenth and Nineteenth Centuries, it is noticed that there are some Heritage constructions have not discussed and have not been concentrated and strongly investigated by researchers. This study seeks to discuss these unpublished Heritage constructions that include a significant layout of architectural styles and structural designs which were varied from one structure to other building during different Islamic ages and continued with architectural and artistic influences during the eighteenth and nineteenth centuries. The methodology of this study will be addressed through descriptive, analytical and comparative study; this will be revealed through discussion, investigation, analysis that can be detected through detailed interrogation of the objects, elements and structure of the content of this study.
\end{abstract}

Keywords: Heritage, Architecture, Eighteenth and Nineteenth Centuries, Gardens, Inspired Architectural Features.

\section{Introduction}

Pavilions are temporary buildings in a large common green area known as garden that was attached to the royal palaces, nobles residences and historical or heritage buildings. The pavilion usually has open sides and is used for recreation, formal and informal celebrations and military processions or other public events such as exhibitions and commercial purposes. In the field of architecture and architectural terminology, the pavilion refers to a dependent building which is either prepared separately or as an extra part or extension to the major building. Therefore, the official residences, royal palaces or other great houses may have one or more dependent pavilions which are either separated or connected by covered passageways or the so-called walkways connecting several parts of a building or any wide path in a garden. Pavilions have small outbuildings of palace gardens that look like kiosks or summer houses, where the kiosks or summer houses were small garden pavilions open on some or all parts of the building. Pavilions, kiosks, summer houses or the so-called tea houses usually have roofs supported by columns with partly or completely open walls. The Pavilion was one of the architectural elements attached to the gardens and palaces, where it was found in the gardens and palaces of the Fatimid era and continued to exist throughout the Islamic ages until the Ottoman period and during the reign of Muhammad Ali dynasty. The functional purpose of the royal pavilions as well as pavilions of emirs and nobles was to follow military parades and official ceremonies, whereas the pavilions found in public gardens were used to enjoy nature watching, spend leisure times and recreation. The pavilions were also used for commercial purposes as is the case in agencies and Khans during Islamic times. The materials used to construct the pavilions were varied between stones, bricks, wood, and sometimes pottery and metals. This study will focus on some unpublished pavilions/kiosks in Germany during the eighteenth and nineteenth centuries; it will also highlight and reveal these unpublished pavilions in Germany, dating back to the $18^{\text {th }}$ and $19^{\text {th }}$ Centuries through an analytical and comparative study. 


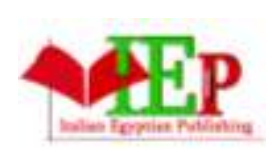

ISSN: $2735-4415$
INTERNATIONAL JOURNAL OF

MULTIDISCIPLINARY STUDIES IN ARCHITECTURE

AND CULTURAL HERITAGE

VOLUME 4, ISSUE 1, 2021, $152-187$.

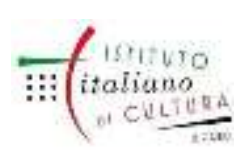

www.egyptfuture.org/ojs/

The objectives of this study will be revealed through discussion, investigation, analysis that can be detected through detailed interrogation of the objects, elements and structure of the content of this study, particularly as a basis for explaining the content and significance through the discussion and interpretation. All of this will be clear through the methodology, structure and content of this study.

\section{The Methodology and Structure of the Study}

\subsection{A General Overview of the Gardens in Germany}

Germany has several gardens and parks which are proper destinations to spend holidays and enjoy the beauty of nature and its bright colors. The interest in establishing gardens has increased due to the civilizational development because one of the important aspects of civilization is the design of gardens since it reflects how cultural and civilized nations are (Jirn 2005). The need to feel the beauty and refined taste was an essential necessity like food and housing (Rawas 1991; Wilson et al. 2004). It is noteworthy that establishing gardens in cities has become a life style to the extent that all city sectors cooperate to choose the optimal type of gardens let alone how to design it. As a result handling plants and trees will be done properly (Winkler and Maier 2019). The garden either private or public is one of the main factors that influence man's health. So, the green spaces should play a key role in physical, mental and social structuring and integration. Accordingly, it goes without saying that human health is not separate from the characteristics of the surrounding environment (Salama 2013). As for the private gardens which surround the houses, they reflect the social class of the house residents through the general structure, the style and the architectural planning not to mention the owned plants (Skowski 2013). The existence of gardens inside cities improves their weather conditions, as well as protecting the environment from pollution and alleviating high temperature (Shama et al.2014). It is worth mentioning that the gardens and landscapes in general increase the purchasing power of the houses and their surrounding buildings due to the existence of outlets that encompass these houses let alone the aesthetic value and the environmental balance brought about by these gardens (Harris 2012). Usually, the scope of the garden extension depends on certain criteria that are relevant to the factors of protecting the plants and trees and maintaining the historical and cultural style of the garden or what could be called the identity of the garden (Szücs and Jaszczak 2013). During the $19^{\text {th }}$ century, the rich's gardens spread in Europe and the artists during the Renaissance age gave attention to portraying gardens and to their functional role in their portraits since they are symbols for prosperity, richness and refined taste and this led to the spread of gardens at that time.The scope of the garden included castles, palaces and houses, but over time, changes were inevitable in the structures and designs of the gardens. So, the designs of the gardens varied during the $18^{\text {th }}$ century and the beginning of the $19^{\text {th }}$ century as follows:

1. Geometric design: is characterized by geometric shapes and right angels as it reflects the required idea on application or refers to acertain theory or concept.The European gardens were influenced during that time with the Italian and French ones(Engelbrecht 2017; Sim 2015).

2. Natural design: is observed the simulation of nature as much as possible as well as the amount of proportion with the large spaces (El-Ghobashy and Mosaad 2016).

3. Mixed design: is a mixed style of the geometric and natural designs which maintains landscapes (Ali 2012).

4. Traditional design: is based on the inherent qualities of materials used in the construction, and this is in addition to modern techniques of building, where traditional and historical shapes should be merged with simplified and clarified geometrical shapes. The traditional design of buildings in diffrent civilizations reflect the local or regional environment as a 


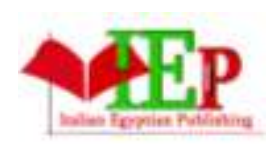

ISSN: $2735-4415$
INTERNATIONAL JOURNAL OF

MULTIDISCIPLINARY STUDIES IN ARCHITECTURE

AND CULTURAL HERITAGE

VOLUME 4, ISSUE 1, 2021, $152-187$.

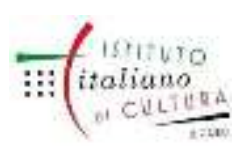

www.egyptfuture.org/ojs/

reaction to the needs and requirements of society and as as a result of the distinctive interaction between the mental abilities of humans and experiences obtained from observing the surrounding natural phenomena(Yuksek 2013; Ulusoy and Kuyrukcu 2012; Yuksek and Esin 2010).

5. Modern design: is the European style which is characterized by simplicity and is not governed by the applicable coordination rules such as axles and symmetry operations. It is often used for growing plants in relative numbers (Ali 2012), and this model of the designs is the layout that that has largely existed and has become widespread together with the models of pavilions that are the subject of the study.

Accordingly, it is worth mentioning that there are influential factors in establishing gardens including the intellectual, civilizational and cultural levels of the area where the gardens are set up. Another influential factor is represented by the experience of the designer, his techniques and creativity (Sukopp 2003).

\subsection{The Origin and Emergence of Pavilions}

The architectural establishments should have an origin. In this sense, no art is created suddenly, and each establishment or architectural element has an origin and roots either this is represented by other civilizations or the same civilization to which the establishment belongs. The architectural origin and functional purpose of pavilion have been traced and it is noticed that there are styles similar to it in the Pharaonic eras as well as through the historical and cultural eras till the epoch of Mohammed Ali's dynasty inside Egypt and beyond.The pavilions existed in the Pharaonic eras and were named a chapel or a rest area (Transit place), which were used as a rest area for gods, kings and priests, as well as it used for ritual celebrations (Wilkinson 1992; Murnane 1967; Shaw 2003; Kamil 1996; Breasted 1907; Wilkinson 1999). For example, the white chapel dating back to the reign of King Senusret I in the twelfth dynasty of ancient Egypt (Elizabeth 2006; Arnaudiès, Beaux and Chéné 2015; Lacau and Chevrier 1956), as well as the red chapel dating back to the reign of Queen Hatshepsut in the eighteenth dynasty of ancient Egypt (Carlotti 1995; Larché and Franck 2006; Van Siclen1989; Graindorge 1993) (Figures 1-2).

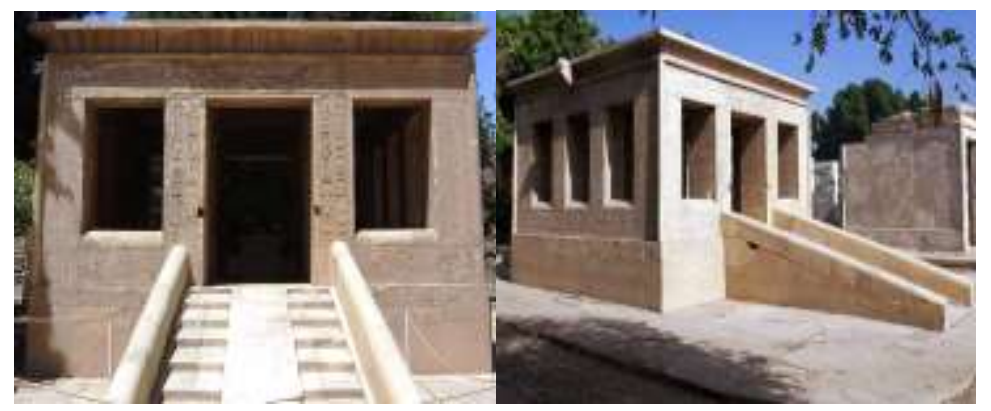

Figure 1: General features of the white chapel of King Senusret I (By the researcher) 


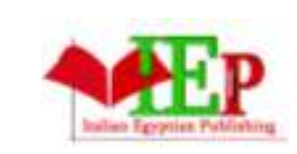

ISSN: $2735-4415$

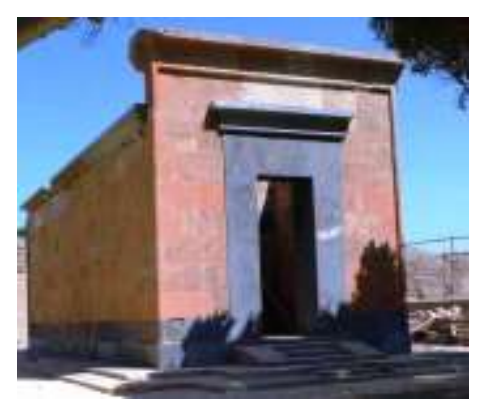

Figure 2: A general view of the red chapel of Queen Hatshepsut (By the researcher)

Both chapels were discovered in the Complex of Karnak Temples, now exist and have been reconstructed in the so-called open-air museum of Karnak Temple in Luxor-Egypt (For more about Karnak Review: Sullivan 2010; Barguet 1962; Marriet 1875; Alliot 1946). The white chapel or white shrine of King Senusret I was referred to as the jubilee or celebration chapel which made of limestone, whereas the red chapel of Queen Hatshepsut was made of red quartzite along with a granite base. The ancient Egyptian language was referred to these chapels as a place of leisure and enjoyment, as well as a lounge of gratification and pleasure (For the name, model, functional purpose and layout of thes chapels Review: Chevrier 1955; Chevrier 1938; Pillet 1923; Chevrier 1928; Porter and Moss 1972; Pillet 1924; Lacau and Chevrier 1977; Grassart-Bleses 2017) (Figures 1-2). In addition to the existence of pavilions during the pharaonic eras, they existed in Islamic eras within the scope of gardens and beside palaces, where the historian Al-Maqrizi (The full name is Taqi al-Din Abu Al-'Abbas Ahmad ibn 'Ali ibn 'Abd Al-Qadir ibn Muhammad Al-Maqrizi (ca1364-1442AD), where he was an important historian during the Mamluk era and interested in the role of Fatimid dynasty in Islamic history of Egypt. For more Review: Rabbat 2003; Walker 2002), and Al-Maqrizi noted that Cairo gardens included pavilions with the aim of enjoying the summer's fresh air and its breeze since the River Nile is near to this area and makes its weather mild during night time in summer season (Pradines and Rahmat 2016). Pavilions do not only exist in Egypt but are also in Jordan, Iraq during the Abbasid era, where these pavilions were discovered by the excavations conducted in these countries. Pavilions were square areas overlooking the outer space through arches and over time these arches were closed by rows of stones (D'hulster and Steenbergen 2013). Pavilions were also established in the Fatimid's gardens for rest, enjoyment and watching the social and military activities taking place in the surrounding area. Therefore, the pavilions were spread in the gardens of Fatimid dynastyor the so-called Fatimid caliphate in Cairo (For more information Review: Cortese 2014; Brett 2001; Lev 1987; Canard 1965), and this was due to the many celebrations and ceremonies held by the Fatimids (Pradines and Rahmat 2016). It is worth mentioning that pavilions were also known during the Seljuk era or the so-called the Seljuk Empire in Turkish cities (For more information Review: Peacock 2015; Harris 2014; Christian and Songül 2012; Grousset 1991), where these pavilions were set up beside palaces and their yards. The functional purpose of these pavilions was being a rest area during journeys for princes and nobles and watching entertainment festivals and sporting events. Moreover, the pavilions were existed at the mountain tops and heights and took the shape of a square or rectangle section overlooking the outer space through arches (Krabbenhöft 2011). The pavilions or the so-called kiosks were widespread during the Ottoman era in Turkey (Freely 2011; Avcioğlu 2008; Avcioğlu 2003). An example of these pavilions is the one inside Koza Hani (For more information Review: Imran, Selen and Tülin 2019; Goodwin 1997; Baykal 1982; Gabriel 1958), which was a shop or the so-called Khan (For more information Review: Hathaway 2013; Boyle 1978 A; Boyle 1978 B; 


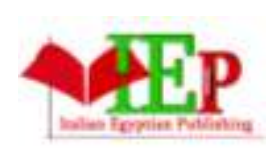

ISSN: $2735-4415$
INTERNATIONAL JOURNAL OF

MULTIDISCIPLINARY STUDIES IN ARCHITECTURE

AND CULTURAL HERITAGE

VOLUME 4, ISSUE 1, 2021, $152-187$.

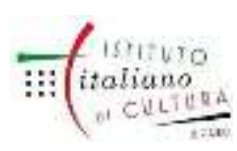

www.egyptfuture.org/ojs/

Krader 1955; Henning 1952), and it is a market area for selling vegetables and fruits, this pavilion existed in the central body of the shop and dated back to 1470 A.D, and was established upon instructions of Sultan Mohammed II (Mohammed Al-Fatih) (For more information Review: Ammalina 2014; Ezad, Ammalina and Mohamad 2014; Freely 2011; Halil and Suraiya 1997), and this was in Bursa area of Turkey (For more information Review: Altintas 2010; Dostoglu, Kitagawa and Asami 2004; Acun 2002; Dostoglu and Vural 2002). Moreover, the Ottoman sultan Bayezid II (For more information Review: Parry 1976), who gave an order to construct the caravanserai in 1490-1491AD/896 AH, this in order to provide income for the sultan's mosque in Istanbul (Imran, Selen and Tülin 2019; Demiralp 1999; Goodwin 1997; Baykal 1982; Gabriel 1958). It is noteworthy that this pavilion (Freely 2011; Halil and Suraiya 1997) is characterized by being large in space and consists of two floors; the first floor is a fountain, whereas the second one is ascended through a marble ladder and takes the shape of an octagon section. The first floor overlooks the outer space through semicircular arches, while the second floor overlooks the outer space through rectangular windows covered by patterns of metal fanlights or grills that is known as Musaba'at that is a grating or screen of metal bars or wires, it is also a metal framework consists of parallel or cross bars, which is used for architectural functional purpose (For Grills or the so-called Gratings Review: Griffith 1911), and there is a solid semicircular arch at the top of each window, this is in addition to the top of this pavilion was covered with a dome having a semicircular section(Figure $3)$.

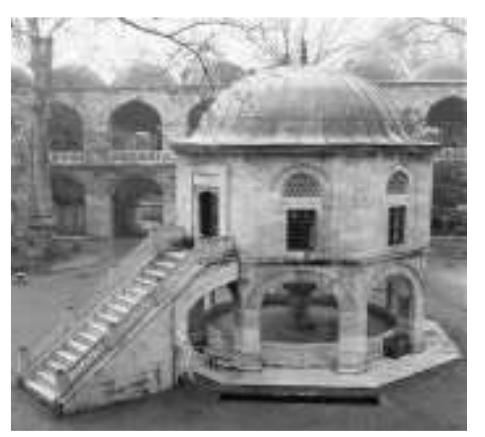

Figure 3: The pavilion of Koza Hant area that is located at the central section of the city called Bursa in Turkey (After: Freely 2011).

The previous pavilion in Bursa area is a large rectangle design surrounding a central courtyard, which is bordered by a two-section corridor, where there are many rectangular sections on both floors of the pavilion, and the main entrance is on the northern part of the building which looks like a great portal (Imran, Selen and Tülin 2019; Demiralp 1999; Goodwin 1997; Baykal 1982; Gabriel 1958). It is apparent from the general structure of the building of this pavilion that it is used as a rest area and for concluding trade agreements between top traders due to its existence inside the agency or the so-called Khan (For Khan, Market and Agency Review: Hathaway 2013; Boyle 1978 A; Boyle 1978 B; Krader 1955; Henning 1952). In Edirne Sarayi or the so-called Edirne Palace (Edirne or the so-called Adrianople is the capital city established by Hadrian who was the Roman Emperor; Edirne is located in the northwestern Turkish zone in the region of East Thrace, which is close to the borders of Turkey with the cities of Greece and Bulgaria. For more information Review: Gökbilgin 1991; Wasti 2004), there is a pavilion built by the architect Sinan Pasha(Sinan is the chief architects of Ottoman Empire, circa 1488 to 1588 A.D.; he lived during the reign of Ottoman Sultans Suleiman I the Magnificent, Selim II, and Murad III. For more information Review: Necipoğlu 2007; Kuran 1987), and this was in the reign of Sultan Suleiman the Magnificent or the Lawgiver (Suleiman the Magnificent or the Lawgiver who ruled from1520 to 1566 A.D.; he was 
one of the most long reigns of the Ottoman Sultans. For more information Review: Agoston 2009; Howard 1988), but unfortunately this pavilion has been destroyed almost in 1877A.D. by the Russian army and when the army seized the city of Edirne (Freely 2011) (Figure 4).

\section{Figure 4: A general view of Edirne Sarayi built by the architect Sinan (After: Freely 2011)}

The Turkish palaces included kiosks or pavilions that were used for rest, watching celebrations, relaxation during night and enjoying the air breeze (Avcioğlu 2003; Halil 2009). For example, the Revan or Yerevan pavilion was erected by the architect Hassan Ağa who lived during the reign of Sultan Murad IV(For more information Review: Caroline 2005; Roemer 1986), the kiosk of Yerevan or the so-called Revan Köşkü was built almost in1635-1636 AD (Hasan 2008 A; Hasan 2008 B) (Figure 5).

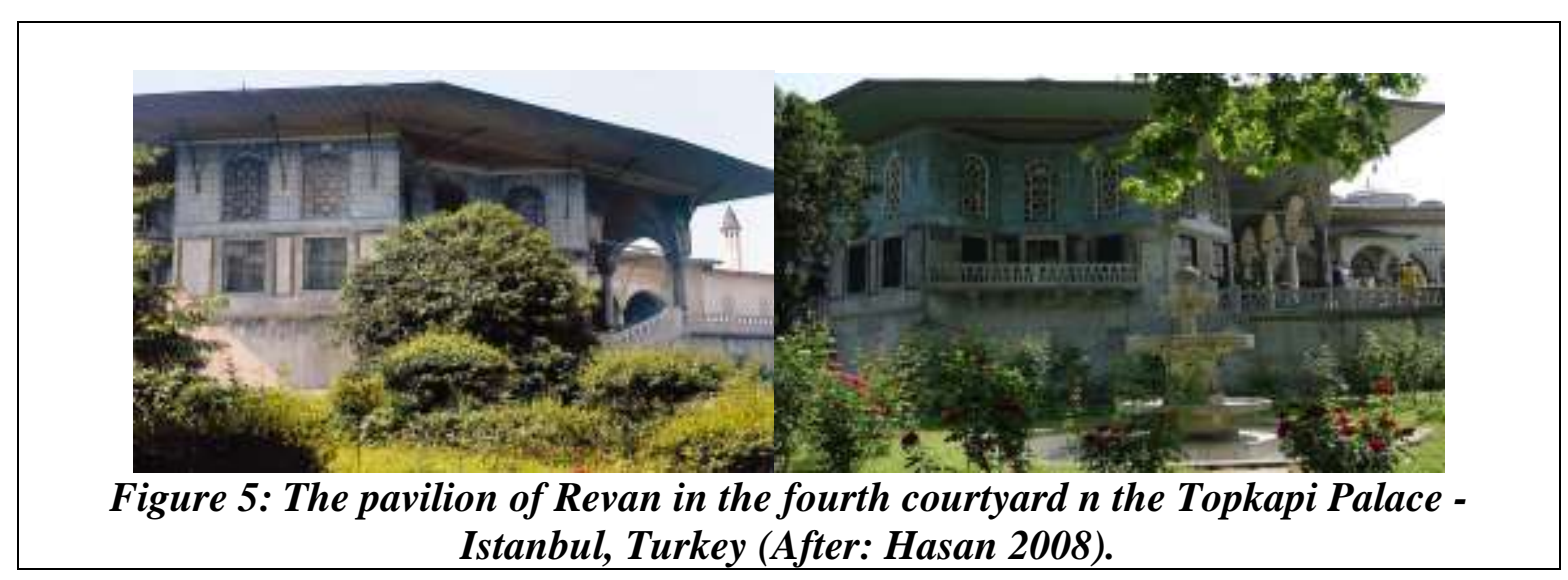

In addition to the Baghdad pavilion or so-called Bağdat Köşkü (Semavi 1991 A; Semavi 1991 B; Freely 2011), whose establishment dated back to 1638-1639 A.D (Figure 6). 


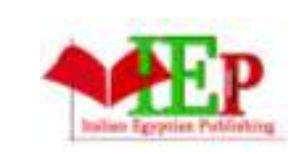

ISSN: $2735-4415$

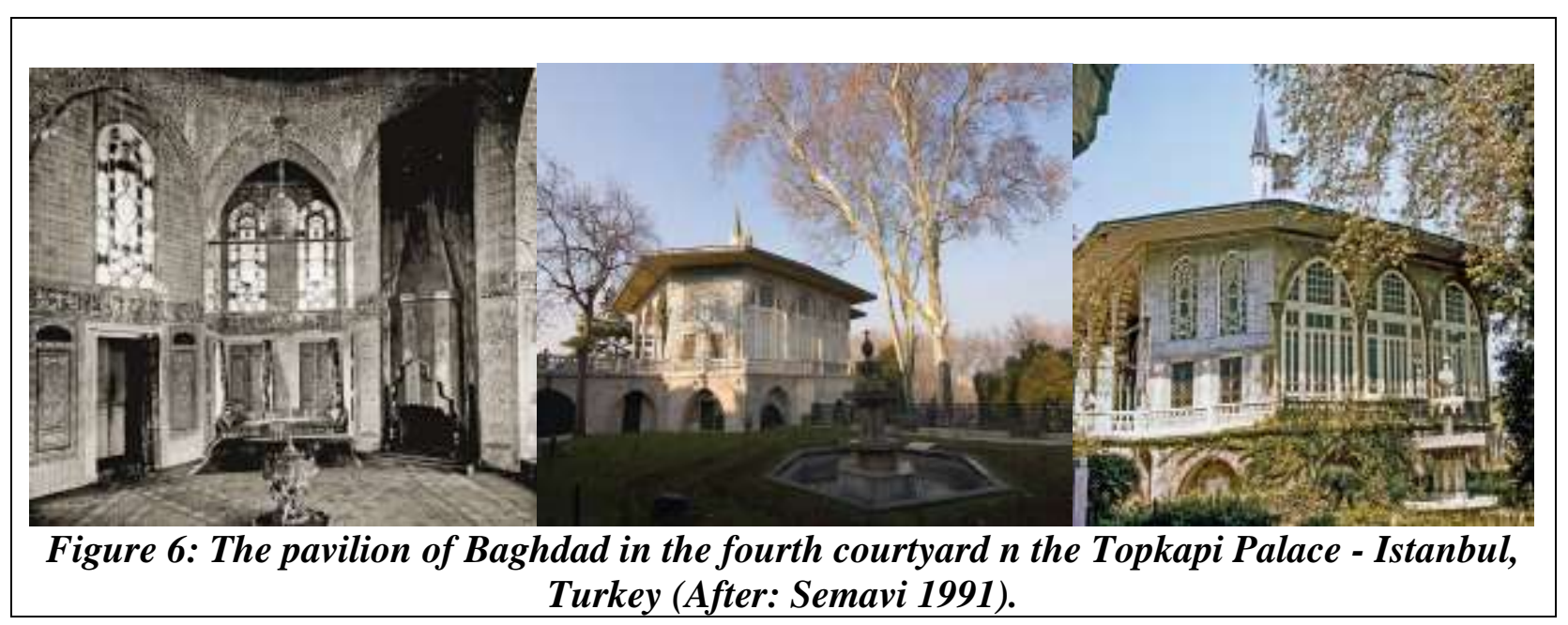

These two pavilions were built in the fourth courtyard within the scope of the Topkapi Palace or the so-called Topkapi Saray in Istanbul (For more information Review: Necipoğlu 1991; Artan 2010; Krahl 1986; Ongan 1940), and this was in order to memorialize the Sultan Murad IV Campaign in Baghdad (Avcioğlu 2003; Halil 2009; Kuban 1996). Both pavilions were built in order to commemorate the Ottoman victories in Yerevan and Baghdad and these two pavilions or kiosks were based on the design of four Iwans together with sofas that extended to the bays taking a rectangular shape. Moreover, the two pavilions or kiosks included eminent frieze with a central dome (Artan 2008; Avcioğlu 2003; Wolfgang 1988; Halil 2009) (Figure 7).
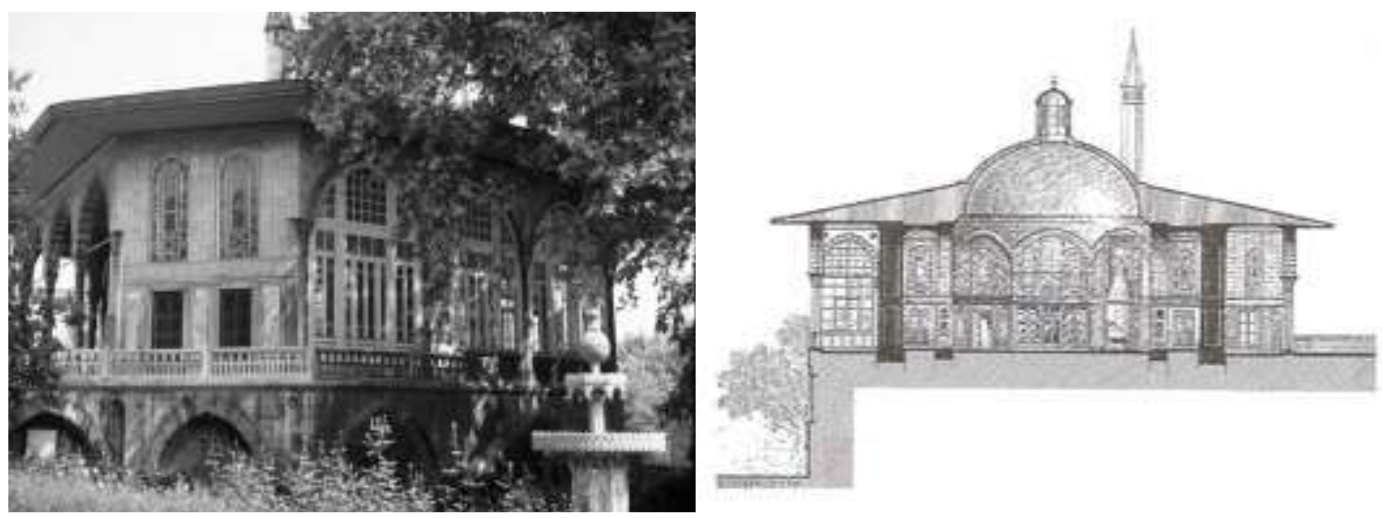

Figure 7: The building design and section of the Baghdad pavilion (After:Freely 2011)

The Baghdad kiosk is a building with an octagon section covered with a dome and consists of two floors; the first floor overlooking the outer space through eight pointed arches, whereas it is noticed that some second floor arches were closed and others were similar to the first floor's arches. The dome was decorated from the inside with colored arabesque decorations while the walls of the second floor were covered by blue tiles of Qashani or Kashani (Freely 2011; Hasan 2008 A; Hasan $2008 \mathrm{~B}$; Halil 2009), as it is noted that the types of marble were used together with tiles on a large scale (Kunt 2006) (Figures 6-7), and it should be noted that the kiosk of Revan or Yerevan (Figure 5) was similar to the Baghdad kiosk or pavilion (Hasan 2008 A; Hasan 2008 B; Halil 2009; Kunt 2006). It is worth mentioning that Turkish pavilions or kiosks during the Ottoman era were portrayed and drawn clearly in the Turkish manuscripts paintings (Avcioğlu 2003; O'Kane 1993), especially the kiosks existed in the Palace known as Topkapi Saray and this is due to its importance, 
as it was the palace of Ottoman sultans over many centuries (Necipoğlu 1991; Artan 2010; Krahl 1986; Ongan 1940). In addition to the Sofa kiosk (Figure 8), which lies in the southern part of Baghdad kiosk and whose date of establishment was not identified definitely yet through the writings on it, as it is worth noting that this kiosk was restored during the reign of Sultan Ahmed III (For more information Review: Keskiner 2012), this was almost in 1704 A.D., once again it has been restored and rebuilt during the reign of Sultan Mahmud I (For more information Review: Kurtaran 2013), and this was almost in 1752 A.D., where it appeared to be greatly influenced by the Baroque and Rococo decorations (Freely 2011; Halil 2009; Sakaoğlu 2015).

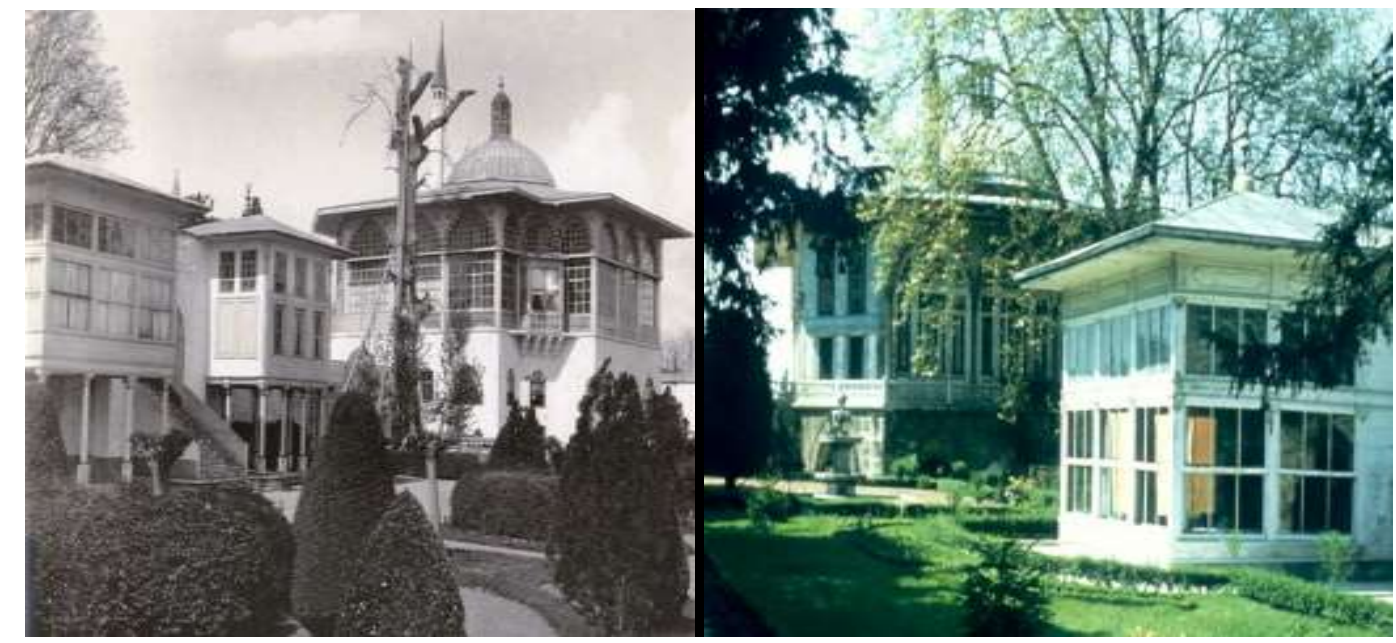

Figure 8: The Sofa Pavilion in the left side of scene, and the Baghdad pavilion in the right side, the Fourth Courtyard, Topkapi Saray, Istanbul.

(After:https://archnet.org/sites/14942; https://archnet.org/media_contents/7713; ;ttps://archnet.or g/media contents/7714 (accessed date 18.01.2020).

The large spaces of gardens and parks arouse the owners of these gardens either they are sultans, princes, nobles, or traders to establish kiosks for enjoyment, relaxation and watching the social and cultural events, where the kiosks become an architectural construction or a building annexed to palaces all over the world and through the ages (Wagner 1988). Furthermore, it is noted that the pavilions continued to exist in Europe as they were found in both traditional and modern forms, which were characterized by being completely built and overlooking the outer space through windows and doors, but they consisted of two floors similar to the traditional kiosks or pavilions, this is like a pavilion existed in Hanover garden in Germany known as 'Gartenpavillon in Herrenhausen', which followed the Baroque style and was established approximately 1709 A.D (Zessin 2015), as well as the building founded under the name 'Privater Rokoko Garten Pavilion' dating back to the second half of the $18^{\text {th }}$ century in the city of Westfalia, western Germany (Peters 2009). In addition to the pavilion of Göttingen garden known as 'Göttingen Gartenpavillon', and whose date of establishment was almost in 1807 A.D (Hoffmann 2010). It should be noted that the last three pavilions will be dealt with in the applied and analytical study.

3. The Descriptive and Applied Study of the Unpublished Pavilions in Germany 3.1. Gartenpavillon in Herrenhausen/ Garden Pavilion in Herrenhausen area Date: 1709 A.D. 


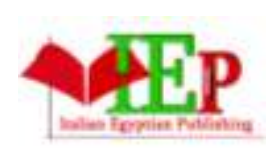

ISSN: $2735-4415$
INTERNATIONAL JOURNAL OF

MULTIDISCIPLINARY STUDIES IN ARCHITECTURE

AND CULTURAL HERITAGE

VOLUME 4, ISSUE 1, 2021, $152-187$.

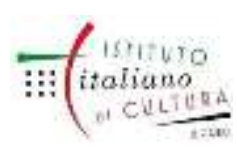

www.egyptfuture.org/ojs/

Site: Herrenhausen Garden in the region of Herrenhausen in Hanover, Germany (Herrenhausen is a region in the city of Hanover which is in northwestern Germany. For more information Review: Alison 1996).

Founder: The British Royal Dynasty in Germany which represented by Electress Sophia, the wife of Prince Ernest Augustus, during her stay in Hanover from 1630 to 1714 A.D. She was influenced to a great extent with the French gardens in particular and the European gardens in general including their palaces and pavilions (Zessin 2015; Vera 1912) (Figure 9).

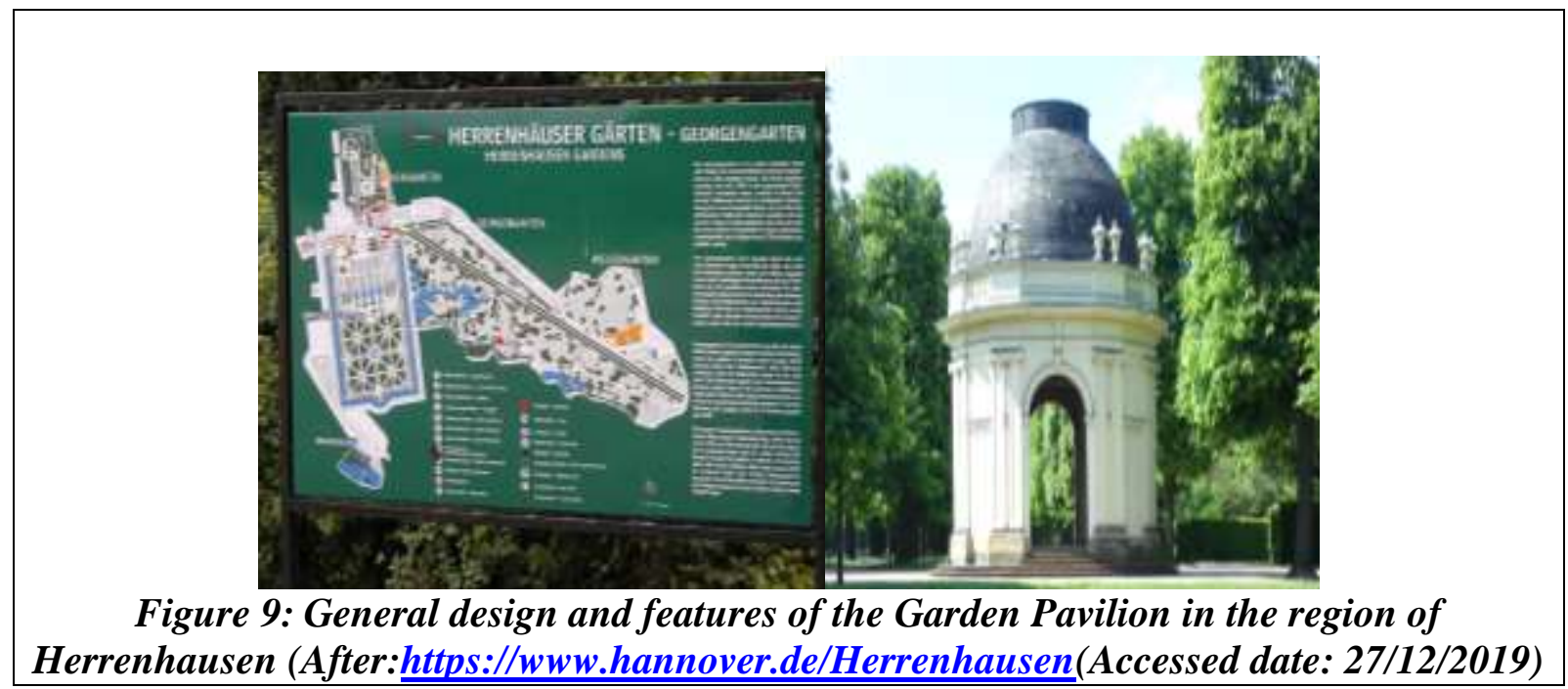

\subsubsection{General Description}

Herrenhausen garden included two pavilions which are similar and lie in the southern part of the garden and these two pavilions follow the Baroque style in terms of the general structure (Zessin 2015). The pavilions take the shape of a circular area which are ascended through three ladder stairs and are opened by two doors which are on the same axis. It is observed that the doors take the form of a half-circular arch, and each door has two columns curved into the wall which have Ionic crowns and extend along the pavilions' wall. The top of these pavilions seem to be covered by a dome that takes the shape of a half circular section and is covered by dark pottery tiles. The neck of the dome is surrounded by a small window overlooking the outer space through a handrail decorated with balusters or the so-called spokes of the balustrade, in addition to the decorative ornaments which are representations of the bell-shaped vases, and these pavilions are painted with stucco (Stucco is a material used in construction, as it was used as a sculptural and artistic material, where the stucco relief was used in the architectural ornamentation projects of many ancient and contemporary cultures. For more Review: Henry and Stewart 2011; Wadsworth 1924) (Figure 10). 


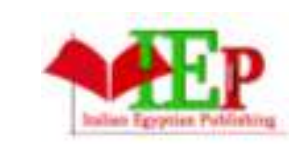

ISSN: $2735-4415$

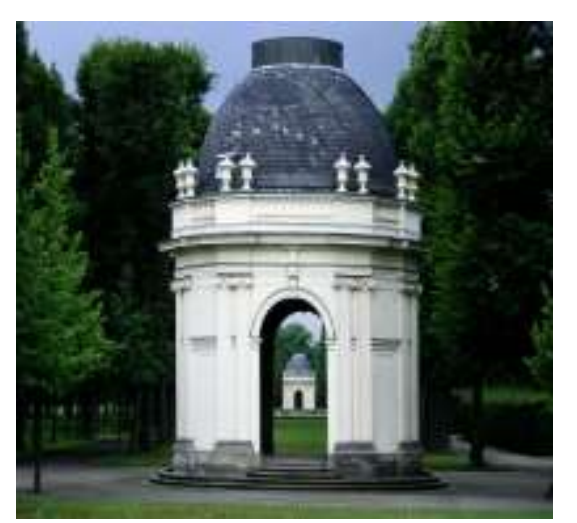

Figure 10: A nearby view of the Garden Pavilion in the region of Herrenhausen (After:https://www.hannover.de/Kultur-Freizeit(Accessed date: 27/12/2019)

\subsection{Privat Rokoko Gartenpavillon / Private Rococo Garden Pavilion}

Date: 1760 A.D (18 $8^{\text {th }}$ century).

Site: Niederrhein Maas info Nettetal ( Nettetal is a city on the Nette River in the zone of Viersen, which is located in the lower region of the Rhine River in the North Rhine-Westphalia, Germany. For more information Review: Bünermann 1970), and it is in the region of the Lower Rhine (The Lower Rhine region or the so-called in Germany Niederrhein is a province located in the lower section of the Rhine River, which is in North Rhine-Westphalia, Germany. For more information Review: Niebaum and Mache 2011; Cornelissen 1986), and it is in the range of the city of Westphalia- North of Rhine-West of Germany (Westphalia or Westfalen is a province in northwestern Germany; it is also one of the three historical regions of the city of North RhineWestphalia. For more information Review: Heinrichs 1996; Schwarting 2005).

Founder: Johann Hermann Poensgen who was a well-known textile trader at that time (Wagner 2017) (Figure 11).

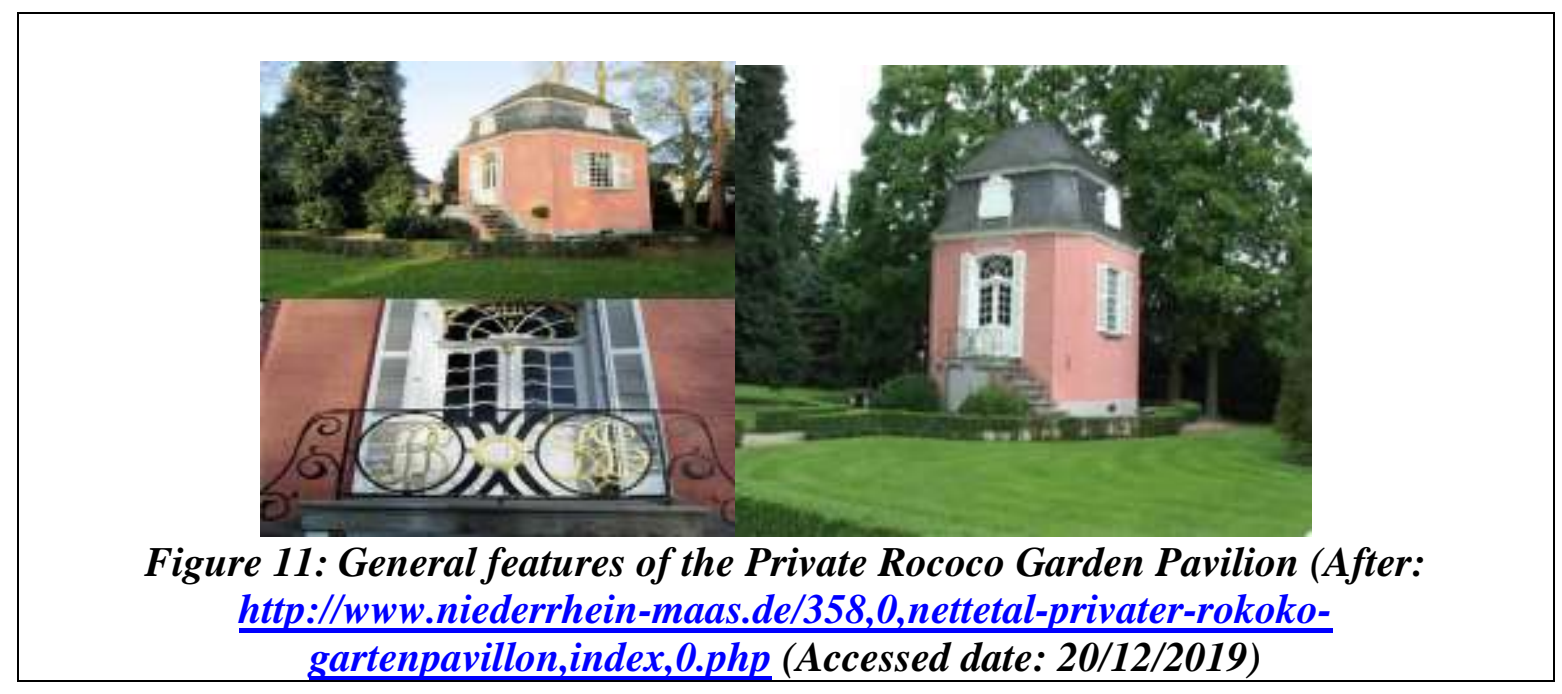

\subsubsection{General Description}

The building is composed of one floor consisting of two levels and made of brick. The pavilion is accessed through a double ladder ending with a metal handrail, to its left the following letters were written (J.H.P) inside a boss or the so-called Jammah, this is in honor of the name of the pavilion 


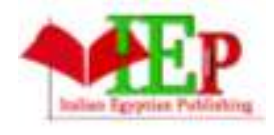

ISSN: $2735-4415$

founder. To the right side of the pavilion, the letters (S.A.S) were written and appeared to be the abbreviation of the name of his wife (Sibilla Adegunde Schmasen). It was noticed that the date of establishing an additional part in 1807 A.D, which came at the middle of the aforementioned letters and was written in a boss or Jammah (The descriptive study from a personal perspective and according to the researcher's analytical view) (Figures 12-13).

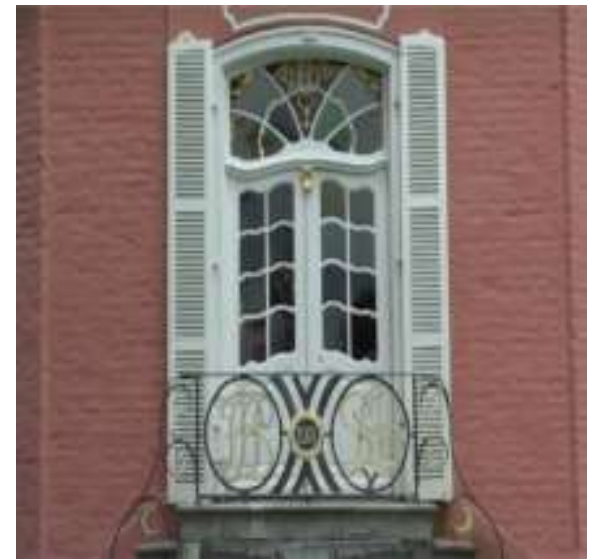

Figure 12: The letters and date written inside a boss or the so-called Jammah in the front window of the Private Rococo Garden Pavilion

(After:http://www.niederrhein-maas.de/358,0,nettetal-privater-rokokogartenpavillon, index, $0 . p h p$ (Accessed date: 20/12/2019)

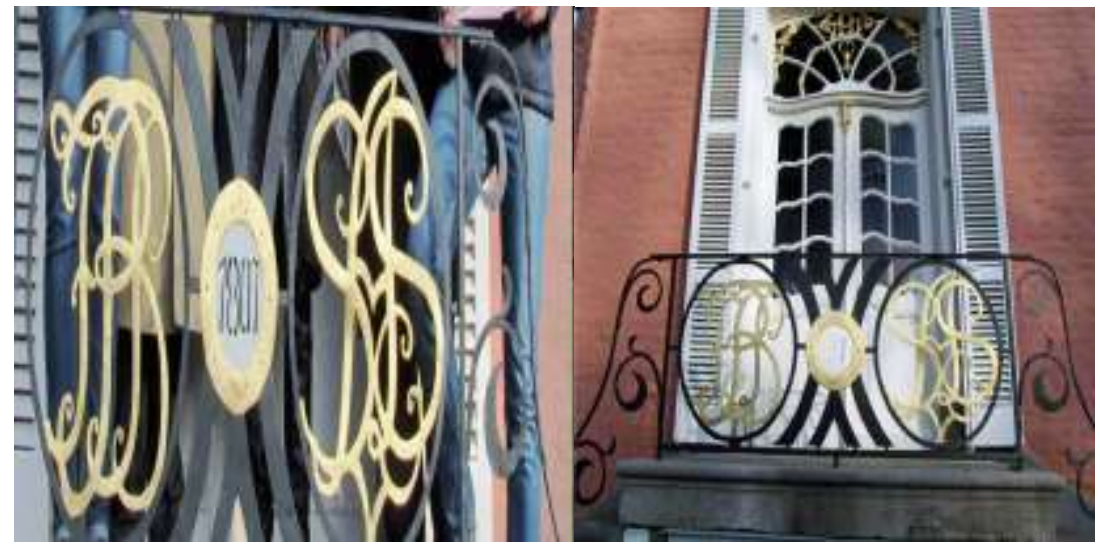

Figure 13: Nearby sights of the letters and date written inside the boss in the front window of the Private Rococo Garden Pavilion (After:

http://www.niederrhein-maas.de/358,0,nettetal-privater-rokokogartenpavillon, index, 0.php (Accessed date: 20/12/2019)

Through the review of literature of Rokoko Pavilion style, it is observed that this pavilion dated back to the second half of the $18^{\text {th }}$ century. Based on the foregoing, the study concludes that the actual date of establishing the pavilion is 1760 A.D. since this pavilion follows the Rococo style in its building design. It is noted that the outside of the pavilion takes the form of an octagon sector whose big sides include glass windows closed by two window shutters, except for the side close to the ladder which ends with a glass entrance door closed from outside by two window shutters. The top of the pavilion is covered by a sloping roof made of dark pottery tiles in two levels. It is 


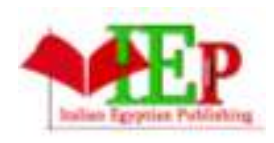

ISSN: $2735-4415$
INTERNATIONAL JOURNAL OF

MULTIDISCIPLINARY STUDIES IN ARCHITECTURE AND CULTURAL HERITAGE

VOLUME 4, ISSUE 1, 2021, $152-187$.

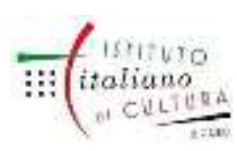

www.egyptfuture.org/ojs/

noteworthy that this pavilion includes a lower level that is accessed through a metal door which is renewed recently. The inside part of the pavilion is free from any embellishments or decorations and is painted with a layer of white cement. It is also characterized by simple and elegant furniture as the pavilion is currently and is sometimes used for holding wedding ceremonies for not more than 20 attendees (The descriptive study from a personal perspective and according to the researcher's analytical view) (Figure 14)

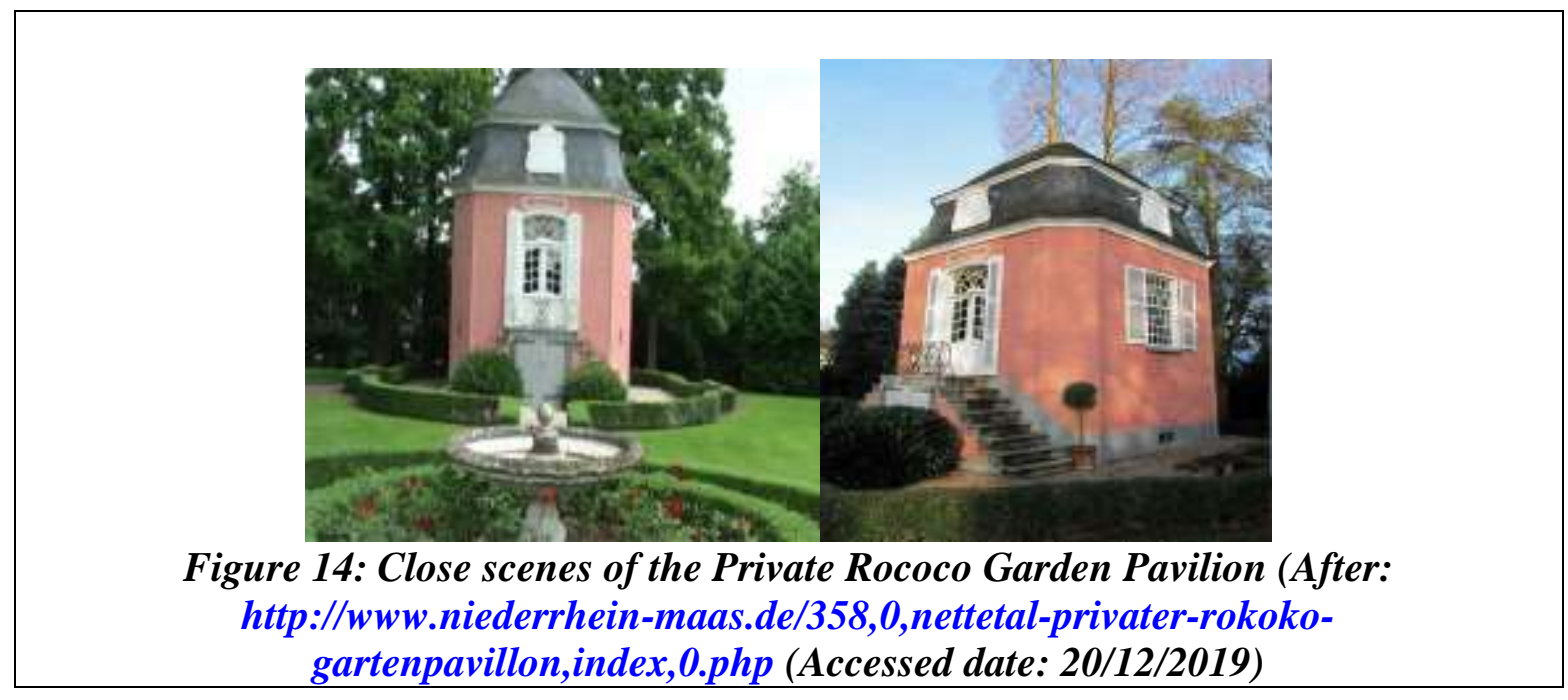

\subsection{Göttingen Gartenpavillon/ Göttingen Garden Pavilion}

Date: $1800-1807$ A.D

Site: Göttingen City - Northwestern part of Germany (Göttingen is a city in the northwestern part of Germany. For more information Review: Levy 2012).

Founder: Jérôme Bonaparte, the King of Westphalia (Jérôme Bonaparte is the brother of Napoléon Bonaparte and was the King of Westphalia in northwestern Germany, where he ruled from 1807 to 1813 A.D. For more information Review: Todorov 2012; Mackay-Quynn 1956; Lamar 2000).

The garden and pavilion were established upon the instructions of the King Jerome Bonaparte. It is worth mentioning that the garden followed the classic style, and during the $19^{\text {th }}$ century this garden was called the green house and now it is called Heute Wangnerstrabe. In 1931, this pavilion was registered among the heritage landmarks with special conservation. In 1935, the garden was resorted to acquire the modern character. In 2004, the pavilion was renewed upon the resolution of the city council of Göttingen. It should be noted that the garden was generally called 'pavilion auf der Schillerwiese (This is according to the identification card adjacent to the pavilion) (Figure15). 


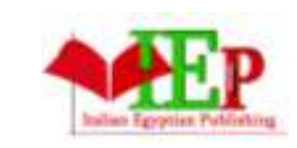

ISSN: $2735-4415$
INTERNATIONAL JOURNAL OF

MULTIDISCIPLINARY STUDIES IN ARCHITECTURE

AND CULTURAL HERITAGE

VOLUME 4, ISSUE 1, 2021, $152-187$.

www.egyptfuture.org/ojs/

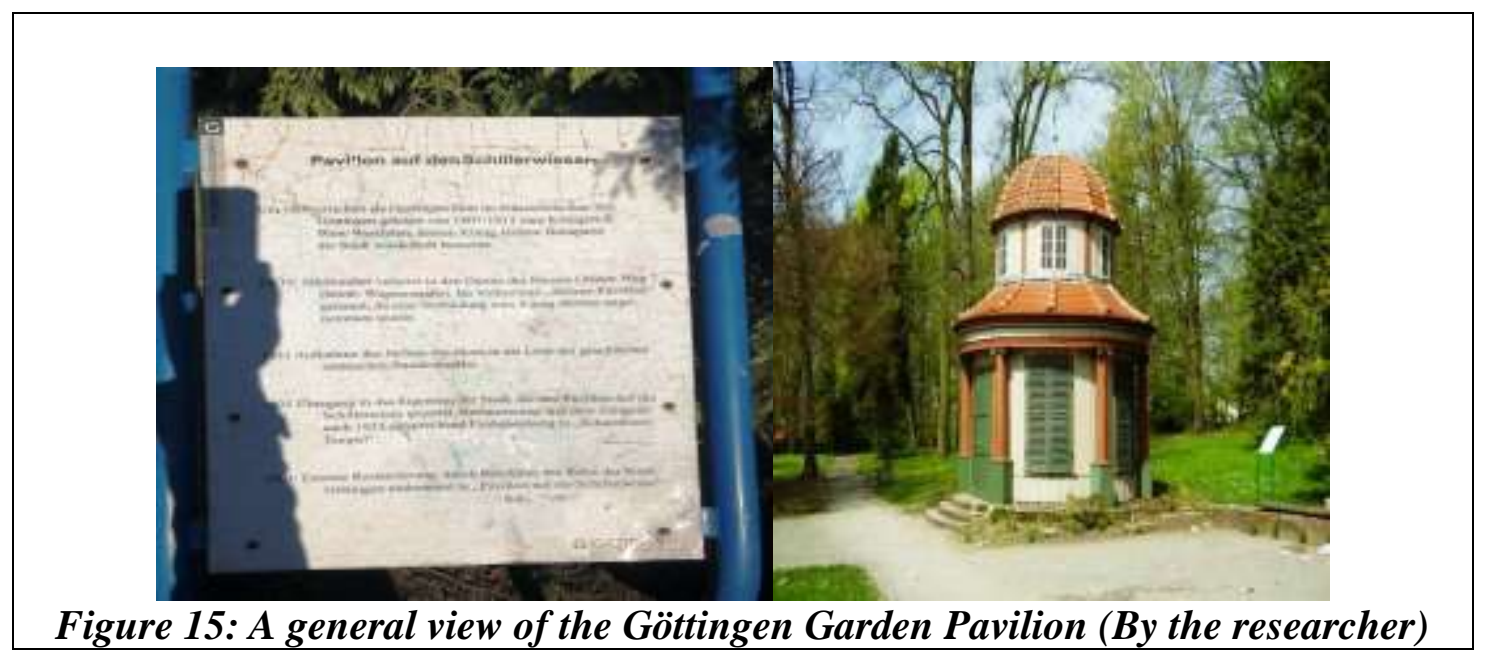

\subsubsection{General Description}

This pavilion takes the shape of a circular area with a diameter of about 7 meters and designed in two floors; the first floor opens to the outer space through a door and five windows with two shutters. An Ionic column separates each window from each other (The Ionic column is one of the three classical architectural styles, the other two columns are the Doric and the Corinthian. Ionic columns are a Greek architectural style characterized by a spiral crown, attributed to the city of Ionia in Greece. For more information Review: Allchin and Erdosy 1995; Al-Bahnasi 1995; Wilson 1989). It is noted that the doors and windows in the first floor are made of wood, whereas the walls are made of brick. A circular section comes at the middle of the second floor which is surrounded by a sloping roof made of brownish pottery tiles covering the roof of the first floor. The second floor overlooks the outer space through 6 rectangular windows made of glass. It is covered by a dome of two levels, the first level which is internal and made of wood; while the second level is external and made of pottery tiles. The dome takes the shape of a half-circular section with a geometric decoration to its bottom which is known in Islamic ages as snake decoration (The descriptive study from a personal perspective and according to the researcher's analytical view and for more information about the serpent decoration and symbolism in Islamic art Review: Kuehn 2011) (Figures 16-17).

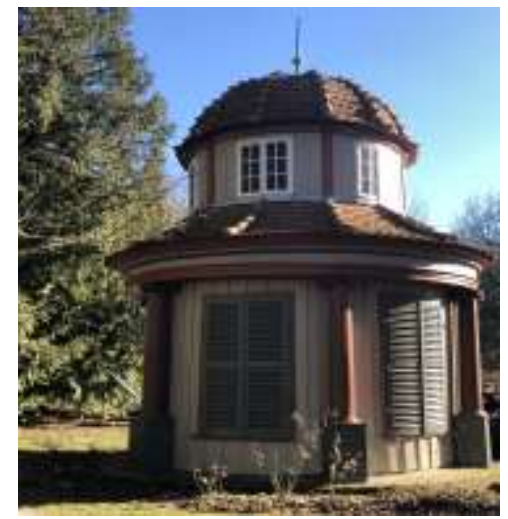

Figure 16: A nearby sight of the Göttingen Garden Pavilion (By the researcher) 


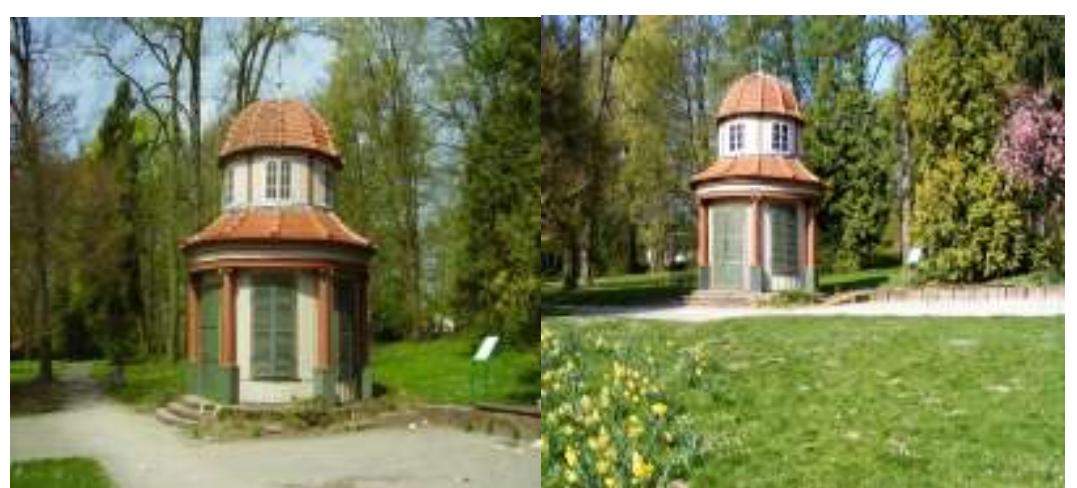

Figure 17: Another scene of the Göttingen Garden Pavilion (By the researcher)

\section{Analytical and Comparative Study}

In the beginning, one wants to clarify the difference between the words Pergola, Pavilion or Kiosk. The difference lies in the building material as the material from which the pergola is made is wood; whereas the pavilion is made of brick or stone. There was impact and influence to a great extent between the pavilions in the Middle East, Turkey, Iran and China. This was crystal clear through the general structure, the building method, the functional purpose for all the pavilions all over the world and this is highlighted by the forms and manifestations of pavilions found in manuscripts (Soltanzadeh and Hassanpour 2015; O'Kane 1993). The term kiosk was widespread in Turkey in particular, where kiosks called pleasure buildings or tea houses due to their use in spending the nighttime, watching celebrations and as a place for looking at the moon quietly at night, where inside the kiosks, delicious foods and drinks were brought during celebrations (Janelis 2010). There was a symbolic purpose for the kiosks and pavilions represented in the pathways of political representation of rule and cohesion (Avcioğlu 2008; Avcioğlu 2003). It should be noted that the kiosks are buildings related with entertainment and leisure time, which are similar to the functional purpose of summer houses and pavilions. The Seljuk kiosks and pavilions during 1038 -1327 A.D. were small structures including a domed hall and open arched parts (Saoud 2003). Kiosks became common in Europe since the $15^{\text {th }}$ century in the Renaissance era. The pavilions or kiosks found in Europe were influenced by the Islamic pavilions and the Turkish kiosks as all of them resembled one another in terms of the general structure and the functional purpose (Hvinden-Haug 2016; Janelis 2010). It is noteworthy that the pavilions in Islamic ages mostly consisted of two floors overlooking the outer space through arcades. Most of the time, a fountain came at the middle of the first floor whereas at modern times and at the beginning of the $17^{\text {th }}$ century, the pavilions consisted of two closed floors overlooking the outer space through a number of windows and doors. The reason behind this may be the difference in temperature and the nature of weather between East and West countries. It is noteworthy that the empty spaces overlooking the Bosporus beaches have allowed more palaces and gardens to be established which in turn led to the interest of Turkish in establishing pavilions which became widespread there (Ozaslan and Akalin 2011). The skillful architects and the factors of transferring the aspects or manifestations of art and the architectural effects from the Eastern countries into Germany posed an influential reason for transferring Germany from a first class industrial society into a society with an artistic and cultural background. This is due to the fact that Germany was influenced by free architecture thinking. One thinks that this term means that the German architecture was influenced by different cultures and civilizations especially those next to it either from the artistic or the technical aspects (Muthesius 1994). Therefore, it can be assumed and concluded that architecture in Germany is characterized by accuracy, beauty and refined taste as a result of its influence by the Turkish architecture with its 


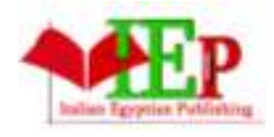

ISSN: $2735-4415$
INTERNATIONAL JOURNAL OF

MULTIDISCIPLINARY STUDIES IN ARCHITECTURE

AND CULTURAL HERITAGE

VOLUME 4, ISSUE 1, 2021, $152-187$.

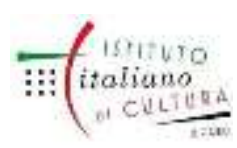

www.egyptfuture.org/ojs/

architectural heritage represented in the Seljuk architecture and Byzantine architecture before it (Ozaslan and Akalin 2011). It is noted that some pavilions in the German gardens were called the octagon halls in gardens, as they take the form of pavilion in terms of the general structure and the functional purpose, which represented in the garden called Brühlschen Garten (Brühlschen Garten is a historical architectural area in the region of Dresden in Germany. For more information Review: Woldemar, Eckhart, and Michael 2006; Barbara 2005; Barbara 2000; Zumpe 1991), where Brühlschen garden located in Dresden-Friedrichstadt (Friedrichstadt is a suburb of Dresden in Germany, whereas Dresden is the capital city of Saxony region in Germany. For more information Review: Szuggat 2012; Bechter 2007; Barbara 2005; Barbara 2000; Zumpe 1991; Fiedler 1904) (Figures 18-19).
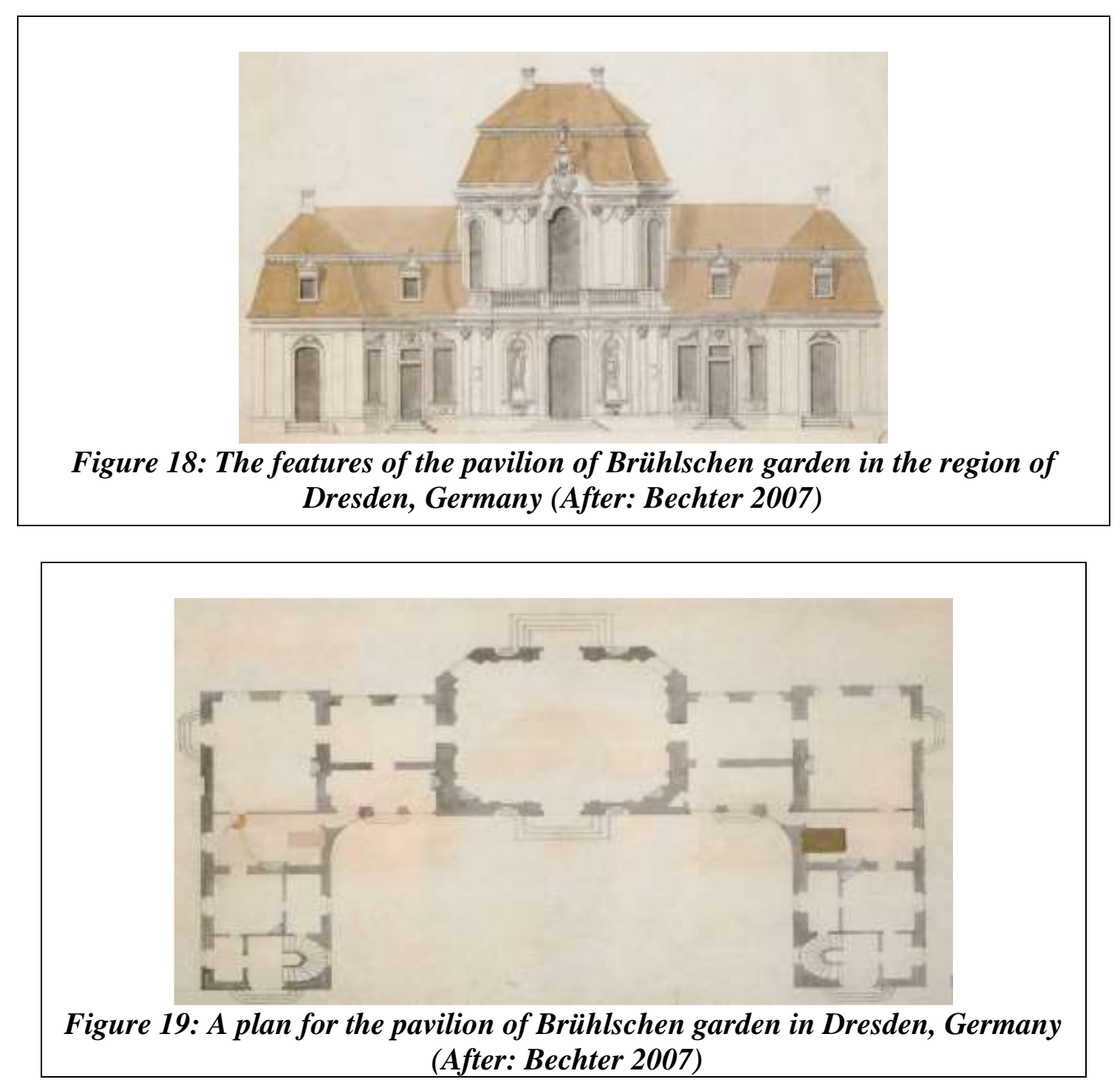

It should be noted that Brühlschen Garten is a historical architectural area in the region of Dresden in Germany, which called at the beginning of the $19^{\text {th }}$ century as the Balcony of Europe (Brühlschen Garten is a historical architectural area in the region of Dresden in Germany. For more information Review: Woldemar, Eckhart, and Michael 2006; Barbara 2005; Barbara 2000; Zumpe 1991). Therefore, it can be said that pavilions were widespread in the gardens and beside palaces in Germany, which were called pavilions or other names such as kiosks or octagon halls, this is 
because all of them had the same functional purpose as well as the general structure in terms of the architectural planning and the artistic style (Bechter 2007; Fiedler 1904). The portrayals of manuscripts or paintings and archival artworks in manuscripts and books showed that pavilions were covered by a sloping roof or a dome like the pavilions found during the $18^{\text {th }}-19^{\text {th }}$ centuries in Germany. It is also observed that the Chinese portrayals and paintings especially during the age of the Emperor Qianlong (Qianlong is the $6^{\text {th }}$ Emperor of the Qing dynasty who ruled China roughly from 1735 to 1796. For more information Review: Zhao 2006; Woodside 2002), which showed the images of European palaces in the background accompanied by pavilions and these were unfamiliar backgrounds in Chinese paintings during the $18^{\text {th }}$ century. So, it turned out that the Chinese knew the pavilions and began to establish them beside their palaces and inside their gardens and pavilions took the general well-known form in Europe and the East (Lillian 2012). It should be noted that the methods of ceiling in European architecture were varied as follows:

1. Metal ceiling which covers a lot of historical and monumental buildings and structures in Europe (Staveteig 2007).

2. Wooden ceiling, where wood was used on a large scale especially for covering houses and various churches. It is scientifically proved that the truss shape which is made of wood, where the loads are distributed in a more technical way and this leads to the spread of wooden ceiling on various levels (Gupta and Limkatanyoo 2008).

3. Ceiling by pottery tiles which is used on a wide scale especially in Europe. Pottery is burnt clay that is either painted or unpainted manufacturing by molding or by primitive methods using the pottery wheel which has old origins and roots (Hussein 2010; Darwish 2002).

Europe became interested during the $18^{\text {th }}$ and $19^{\text {th }}$ centuries in the stages of pottery's manufacturing due to its widespread use, where each establishment and society have the type of pottery that suit it. The pottery which is used for covering churches differs from the one that covers the roofs of houses in terms of the general structure and the color or the technique and the degree of burning the pottery as well as the glazing by a glaze layer. The level of production and its density determine the performance level of the handicraft in meeting the needs of society, where the nobles always try to be distinguished from the rest of society classes (Ali 2012). From the above mentioned, it can be said that the pottery tiles which cover the royal pavilion is distinguished with the dark color and a visible transparent layer, whereas the pottery tiles which cover the pavilion in public gardens are most likely light-colored. The pottery tiles contain nine main types including plain tile, flat tile with interlocking, slightly curved tile with interlocking, interlocking hollow tile, hollow tile, interlocking Roman tile, interlocking molding tile, ceramic slate, and flat cladding tile (Wienerberger Building Solutions, Clay roof tile designed for living- Wienerberger Building Material Solutions, On: https://www.wienerberger-building-solutions.com/About/About/Wienerberger-BuildingSolutions.html\#). It is not possible to disregard the existence of two doors on the same axis in the small Garden Pavilion in the region of Herrenhausen known as 'Kleiner Gartenpavillon in Herrenhausen' (Herrenhausen is a region in the city of Hanover which is in northwestern Germany. For more information Review: Alison 1996), as this architectural phenomenon or idea was found since the early Islamic ages (Darwish 2019; and for more information Review: Doris, 2007; Yeomans 2006; Abdel-Razek 2009). Examples of this phenomenon are represented in the Umayyad Mosque in Damascus - Syria 86 A.H/705 A.D (Grafman and Rosen-Ayalon 1999; Burns 2005), in addition to its existence in other Islamic buildings in Egypt that include but are not limited to AlAzhar Mosque 359 A.H/970A.D (Creswell 1952; Rabbat 1996), as well in Al-Hakim bi-Amr Allah Mosque 381 A.H/991 A.D (Doris 1989B; King 1984; Bloom 1983), also in Al-Salih Tala'i Mosque 555 A.H/1160 A.D (Williams 2008; O'Kane 2012), in addition to the Abbasid Caliphs' Dome or the so-called the Mausoleum of the 'Abbasid Caliphs 640 A.H/1242 A.D (Abd al-Wahhab 1940A; 


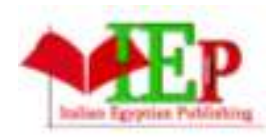

ISSN: $2735-4415$
INTERNATIONAL JOURNAL OF

MULTIDISCIPLINARY STUDIES IN ARCHITECTURE AND CULTURAL HERITAGE

VOLUME 4, ISSUE 1, 2021, $152-187$.

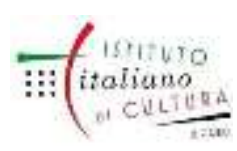

www.egyptfuture.org/ojs/

Doris 1989 A; Creswell 1978), as well in the dome of Shajar Al-Durr or the so-called Mausoleum of Shajar Al-Durr 641 A.H/1243A.D (Ruggles 2015), and in the Mosque of Al-Zahir Baybars AlBunduqdari 667 A.H/1269 A.D (Doris 1989A; Creswell 1978; Doris 2007; Abd al-Wahhab 1940B; Bloom 1982). Therefore, it can be said that the phenomenon of axial doors was common from Islamic times and then transferred to Europe. It should be noted that the European Baroque style was represented in the Baroque pavilion of Wrest Park Gardens in England which built during the early $18^{\text {th }}$ century around 1709-1711 A.D (Taylor 2008; Andrew and Shelley 2011) (Figure 20).

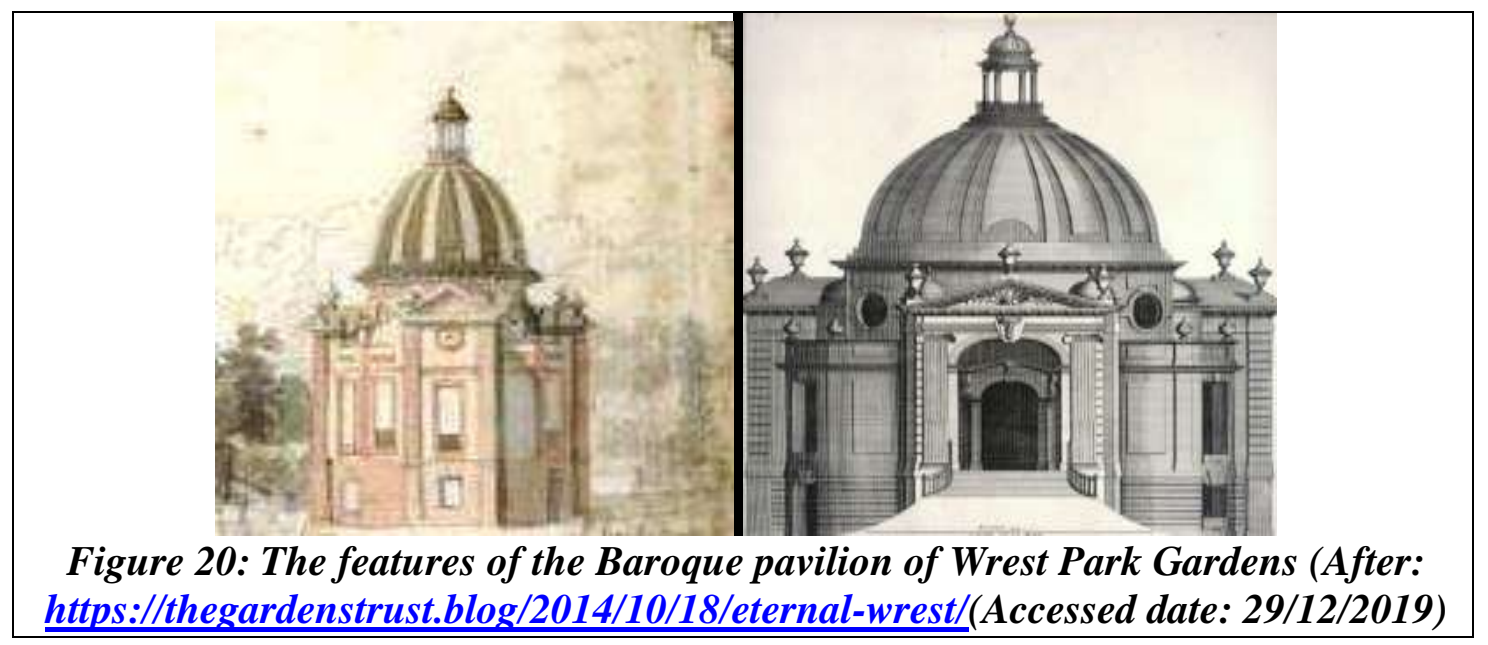

Regarding the Georgian architecture (Georgian architecture is referred to as some architectural styles used between about 1720 and 1830 A.D., relating to the state of Georgia, which were architectural characteristics of the epochs of the British Kings George the first to the fourth roughly circa 1714 -1830. For more information Review: Summerson 2003; Summerson 1993), where it is observed that the Georgian architecture during $18^{\text {th }}$ and $19^{\text {th }}$ centuries was represented in the Royal pavilion or the so-called Brighton pavilion (Brighton is a beach area or vacation resort located in the southern part of London. For more Review: Antram and Morrice 2008), where the Royal pavilion or the so-called Brighton pavilion has classical architectural style and oriental architectural features including arches, domes, crowns and cornices or friezes (Limper-Herz 2013; Myer 1961; Malins 1980; Jackson-Stops 1991; Limper-Herz 2019) (Figure 21).

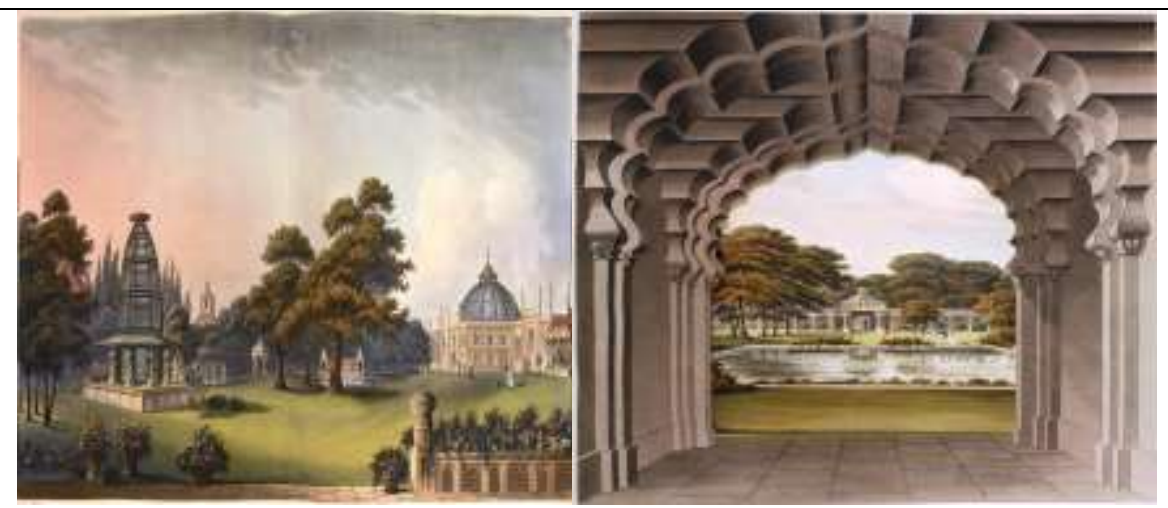

Figure 21: The designs and features of the Royal pavilion in Brighton pictured by Humphry Repton who was the first designer to the Royal Pavilion in Brighton, London (After: Limper-Herz 2019) 


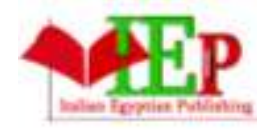

ISSN: $2735-4415$
INTERNATIONAL JOURNAL OF

MULTIDISCIPLINARY STUDIES IN ARCHITECTURE AND CULTURAL HERITAGE

VOLUME 4, ISSUE 1, 2021, $152-187$.

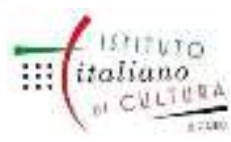

www.egyptfuture.org/ojs/

With regard to Egypt and definitely during the reign of Muhammad Ali (For more information Review: El Ashmouni and Bartsch 2014; Toledano; 1985), where it can be said that Mohammed Ali Pasha was influenced by Ottoman architecture, components of civilization, as well as the European arts at the same time since he was a man open to the world and lover of science and architecture, and a perfect example of this is the kiosk in Mohammed Ali Pasha's palace in Shubra in Egypt (Abdel-rahman 2016; Refai 2009) (Figure 22).

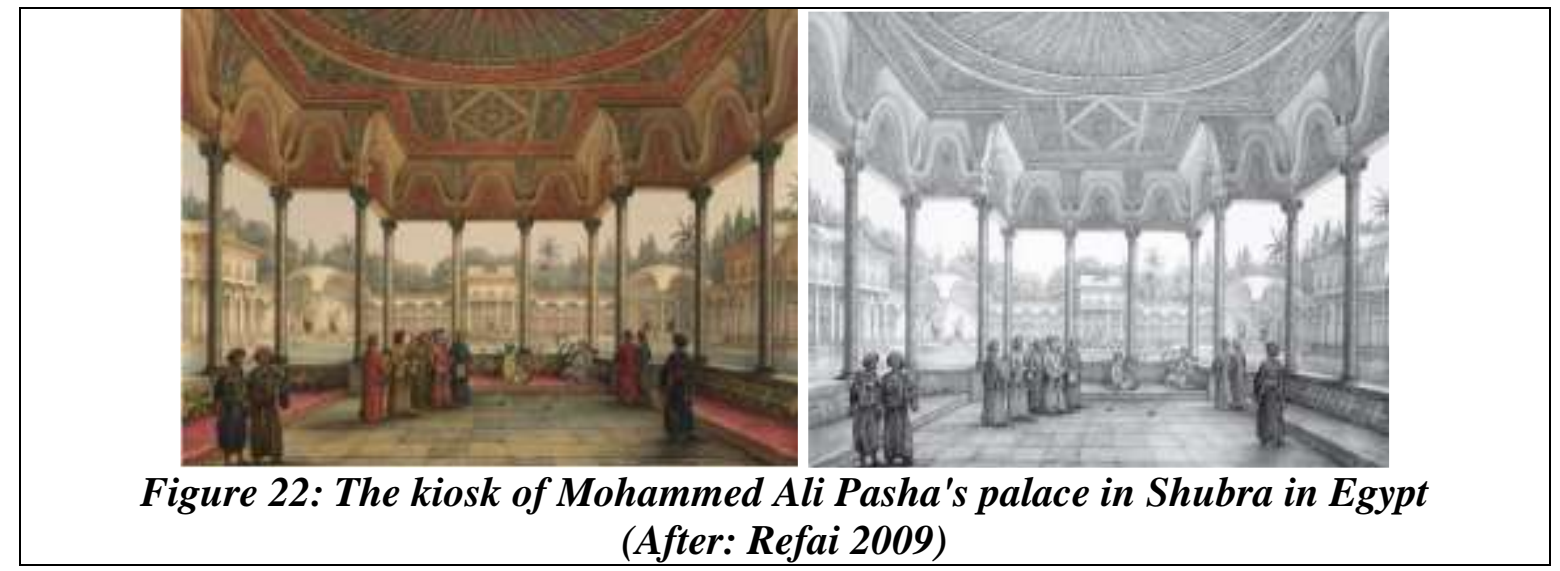

In the zone of Azbakeyah garden in Cairo (Azbakeyah is one of the major regions in Cairo, Egypt, which contains many important establishments and historical buildings. For more information Review: El Kadi 2012; Doris 1985; Sanders 1994), where there is a music pavilion or kiosk in the range of Azbakeyah garden, which established by Khedive Ismail almost in 1872 A.D (Mestyan 2013; Micklewright 2017; El Messiri 2004) (Figures 23-24).

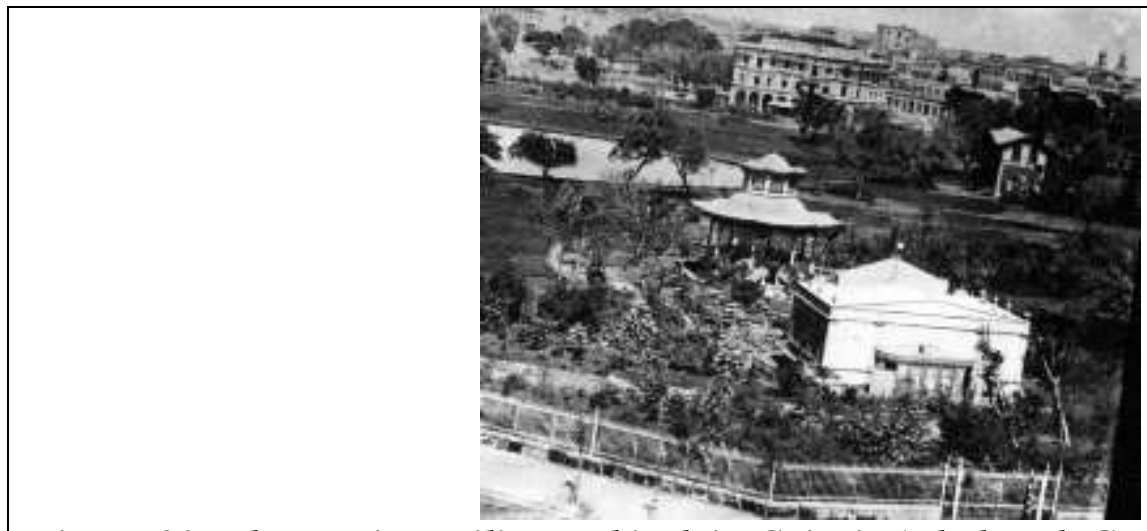

Figure 23: The music pavilion or kiosk in Cairo's Azbakeyah Garden(After: Mestyan 2013) 


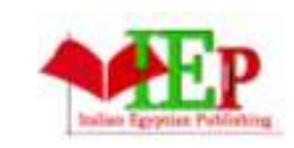

ISSN: $2735-4415$
INTERNATIONAL JOURNAL OF

MULTIDISCIPLINARY STUDIES IN ARCHITECTURE

AND CULTURAL HERITAGE

VOLUME 4, ISSUE 1, 2021, $152-187$.

www.egyptfuture.org/ojs/

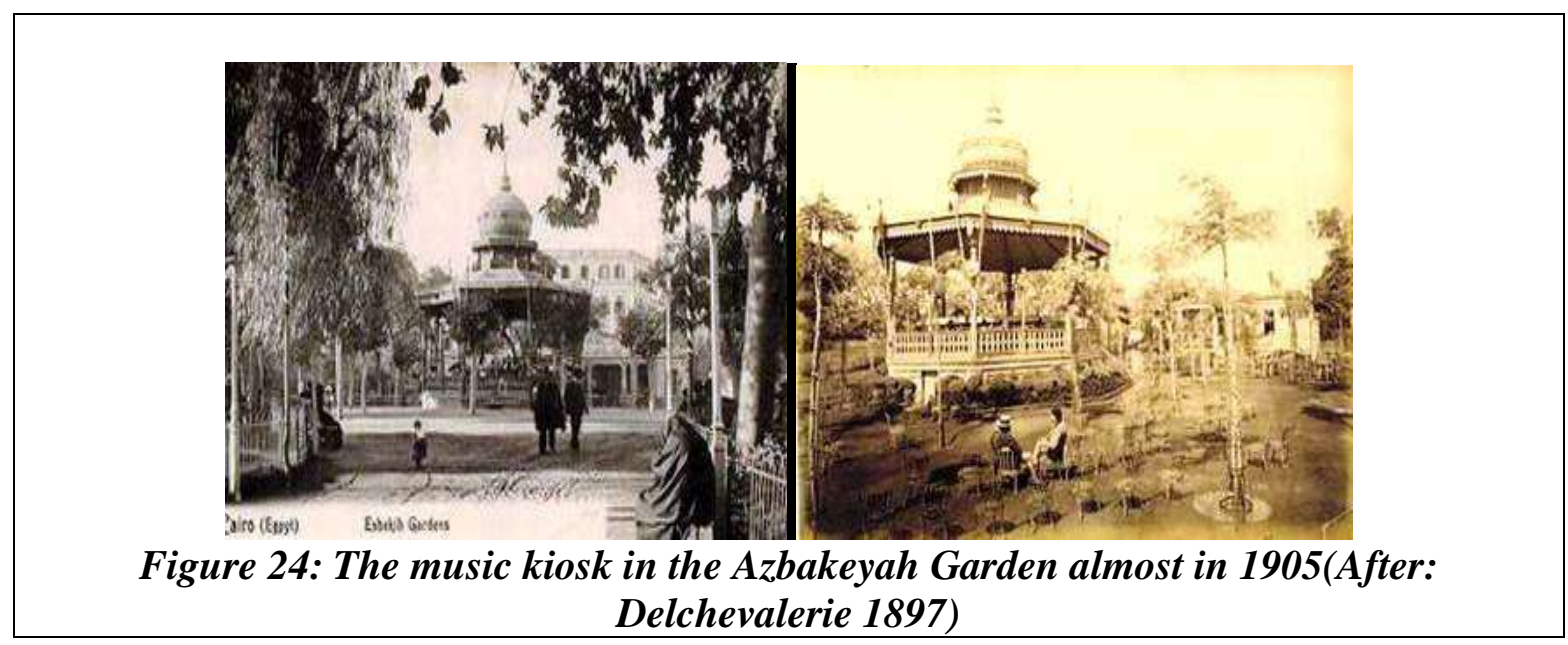

This music pavilion represents the style of metal structures in Cairo during the nineteenth century; it is also one of the recreational facilities attached to the gardens in Egypt. The Azbakeyah garden in Cairo was used as a main base for enjoyment and to spend leisure time and this was due to activities of Khedive Ismail in the representation of modern character or modernism to Cairo and through the urban planning (El Kadi 2012; Volait 2003; Fahmy 2002; Abu-Lughod 1965). By visiting the music pavilion or kiosk in Cairo's Azbakeya garden, it is observed that the design was a semi-circular area constructed and made of metal, including some columns and each column is decorated with lower and upper ribbons decorated with floral motifs, this is in addition to some other ornamentations on the top of the columns, including Ionian and Corinthian crowns, which are composed of floral motifs and spiral shapes. At the top end of each column there is a metal frame with a raised edge decorated with geometric motifs, and above the metal frame, there is a metal dome that takes the semicircular section (The descriptive study from a personal perspective and according to the researcher's analytical view) (Figure 25).

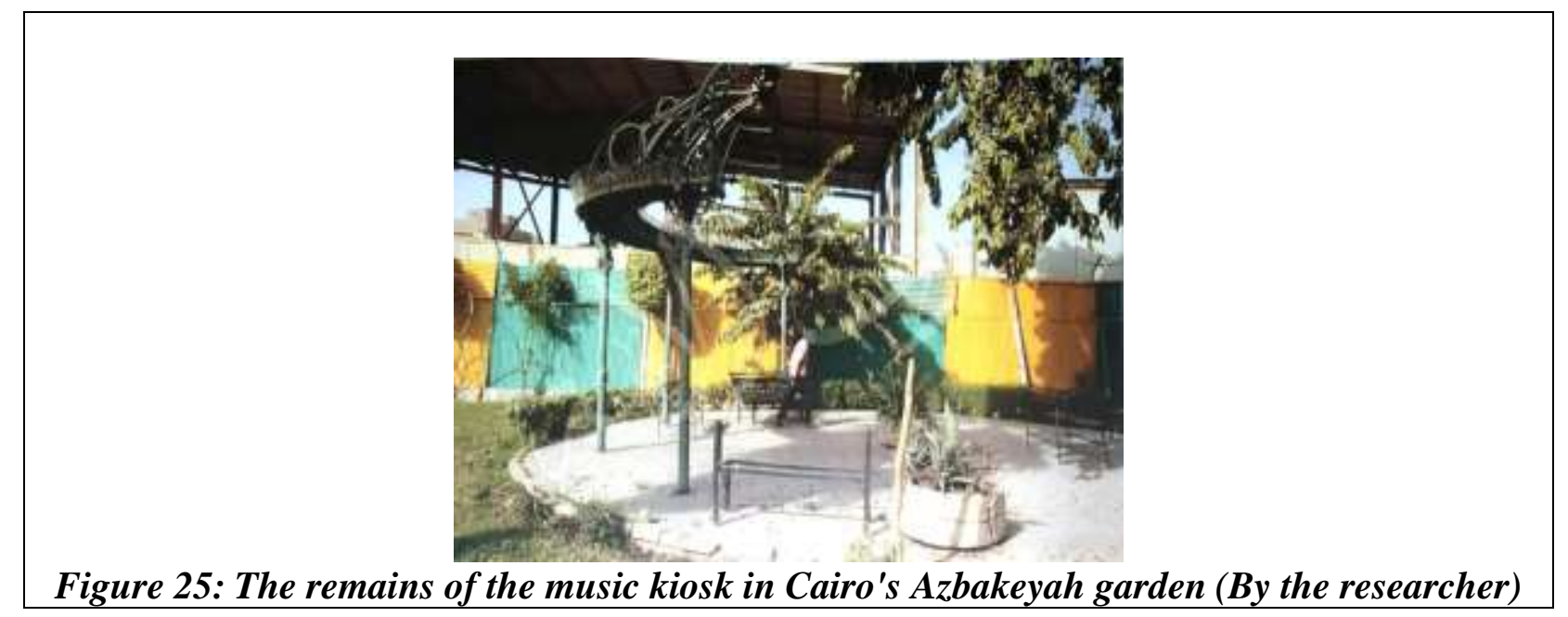

The dome is centered on top of a metal shape or an oval-shaped basket, which was used for placing flowers and plants over the circumference of the dome with its metal beams giving a wonderful aesthetic look (The descriptive study from a personal perspective and according to the researcher's analytical view) (Figure 26). 


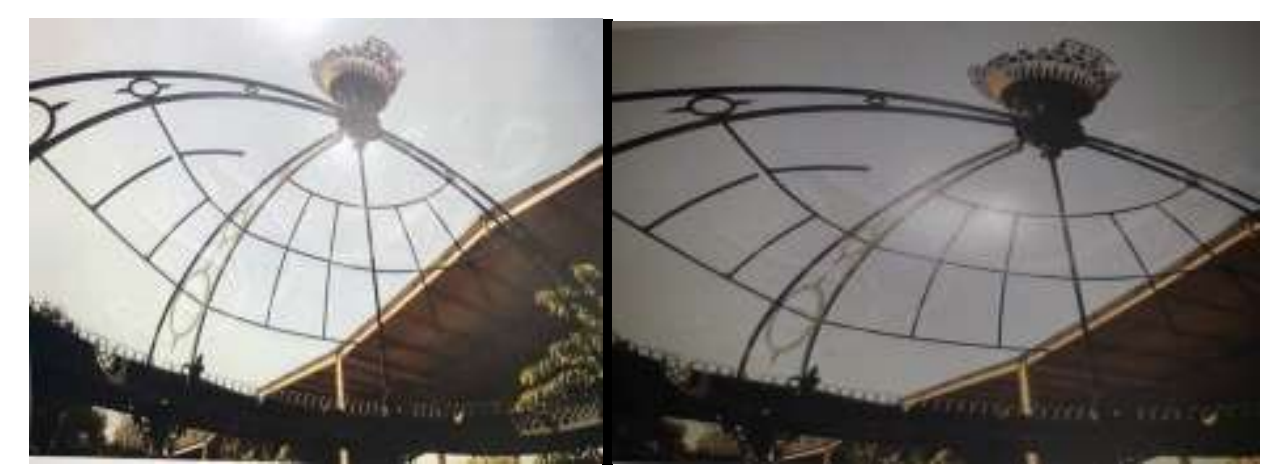

Figure 26: The remains of the dome's circumference with its metal beams of the music kiosk in Cairo's Azbakeyah garden (By the researcher)

It should be noted that this kiosk was used to play music in the presence of the pioneers and visitors of the garden, which is similar to the functional purpose of the pavilion under study, as well as both of them are located in the gardens area. From the above mentioned, it is clear that the pavilions continued to exist in Europe as they were found in both traditional and modern forms, which were characterized by being completely built and overlooking the outer space through windows and doors, however they consisted of two floors similar to the traditional shape of kiosks or pavilions, this is like a pavilion existed in Hanover garden in Germany known as 'Gartenpavillon in Herrenhausen', which is followed the baroque style and was established in 1709 A.D, as well as the building founded under the name 'Privater Rokoko Garten Pavilion' dating back to the second half of the $18^{\text {th }}$ century in the city of Westfalia, western Germany.In addition to the pavilion of Göttingen garden known as 'Göttingen Gartenpavillon', which was established almost in 1807 A.D. The last three unpublished pavilions are discussed above and compared to other similar pavilions in the descriptive, applied, analytical and comparative study.

\section{Conclusion and Analysis of the Study}

This research focuses on three unpublished pavilions in Germany, dating back to the $18^{\text {th }}$ and $19^{\text {th }}$ Centuries through analytical and comparative study. These three Heritage structures have not discussed and have not been concentrated and strongly investigated by researchers. This study seeks to discuss these unpublished pavilions that include a significant layout of architectural styles and structural designs which were varied from one structure to other building during different Islamic ages and continued with architectural and artistic influences during the eighteenth and nineteenth centuries. The methodology of this study is addressed through descriptive, analytical and comparative study, which is revealed through discussion, investigation, analysis that can be detected through detailed interrogation of the objects, elements and structure of the content of this study. The pavilions were a temporary buildings situated in a large common green area or a garden which attached to the royal palaces, nobles residences and historical or heritage buildings. The pavilions usually have open sides and were used for recreation, formal and informal celebrations and military processions or other public events such as exhibitions and commercial purposes. In the field of architecture and architectural terminology, the pavilions refer to dependent buildings which were either prepared separately or as extra parts or extensions to the major building. Pavilions have small outbuildings of palace gardens that look like kiosks or summer houses, which were small garden pavilions open on some or all parts of the building. Pavilions, kiosks, summer houses or the so-called tea houses usually have roofs supported by columns with partly or completely open walls. The Pavilion was one of the architectural elements attached to the gardens and palaces, where it was found in the gardens and palaces of the Fatimid era and continued to exist throughout the Islamic 


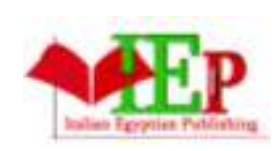

ISSN: $2735-4415$
INTERNATIONAL JOURNAL OF

MULTIDISCIPLINARY STUDIES IN ARCHITECTURE

AND CULTURAL HERITAGE

VOLUME 4, ISSUE 1, 2021, $152-187$.

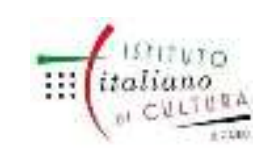

www.egyptfuture.org/ojs/

ages until the Ottoman period and during the era of Muhammad Ali dynasty.The functional purpose of the royal pavilions as well as pavilions of emirs and nobles was to follow military parades and official ceremonies, whereas the pavilions found in public gardens were used to enjoy nature watching, spend leisure times and recreation. The pavilions were also used for commercial purposes as is the case in agencies and Khans during Islamic times. The materials used to construct the pavilions were varied between stones, bricks, wood, and sometimes pottery and metals. This study discussed three unpublished pavilions/ kiosks in Germany during the eighteenth and nineteenth centuries; it is also highlighted and revealed these unpublished pavilions in Germany, which date back to the $18^{\text {th }}$ and $19^{\text {th }}$ Centuries through an analytical and comparative study. Germany has several gardens and parks which are proper destinations to spend holidays and enjoy the beauty of nature and its bright colors. The interest in establishing gardens has increased due to the civilizational development because one of the important aspects of civilization is the design of gardens since it reflects how cultural and civilized nations are. The designs of gardens varied during the $18^{\text {th }}$ century and the beginning of the $19^{\text {th }}$ century including geometric design, natural design, mixed design, traditional design and modern design. It is clear from the origin and emergence of Pavilions that the architectural origin and functional purpose of pavilion have been traced and it is noticed that there are styles similar to it in the Pharaonic eras as well as through the historical and cultural eras till the epoch of Mohammed Ali's dynasty inside Egypt and beyond. The pavilions continued to exist in Europe as they were found in both traditional and modern forms, which were characterized by being completely built and overlooking the outer space through windows and doors, but they consisted of two floors similar to the traditional kiosks or pavilions, this is like a pavilion existed in Hanover garden in Germany known as 'Gartenpavillon in Herrenhausen', which is followed the baroque style and was established in 1709 A.D, as well as the building founded under the name 'Privater Rokoko Garten Pavilion' dating back to the second half of the $18^{\text {th }}$ century in the city of Westfalia, western Germany.In addition to the pavilion of Göttingen garden known as 'Göttingen Gartenpavillon', which was established almost in 1807 A.D. The last three pavilions were discussed and compared to other similar pavilions in the descriptive, applied, analytical and comparative study. From the above mentioned, it can be assumed and concluded that architecture in Germany is characterized by accuracy, beauty and refined taste as a result of its influence by the Turkish architecture with its architectural heritage represented in the Seljuk architecture and Byzantine architecture before it.

\section{Results of the Study}

6.1. There are differences between the words Pergola, Pavilion or Kiosk. The difference lies in the building material as the material from which the pergola is made is wood; whereas the pavilion is made of brick or stone and may be of metal. There was impact and influence to a great extent between the pavilions in the Middle East, Turkey, Iran and China. This was crystal clear through the general structure, the building method, the functional purpose for all the pavilions all over the world and this is highlighted by the forms and manifestations of pavilions found in manuscripts.

6.2. The term kiosk was widespread in Turkey in particular, where kiosks called pleasure buildings or tea houses due to their use in spending the nighttime, watching celebrations and as a place for looking at the moon quietly at night, where inside the kiosks, delicious foods and drinks were brought during celebrations, where the kiosks are buildings related with entertainment and leisure time, which are similar to the functional purpose of summer houses and pavilions.

6.3. Pavilions do not only exist in Egypt but are also in Jordan, Iraq during the Abbasid era, where these pavilions were discovered by the excavations conducted in these countries. Pavilions were also established in the Fatimid's gardens for rest, enjoyment and watching the social and military activities taking place in the surrounding area. Therefore, the pavilions were spread in the gardens 
of Fatimid dynasty or the Fatimid caliphate in Cairo, and this was due to the many celebrations and ceremonies held by the Fatimids.

6.4. Pavilions were known during the Seljuk era or Seljuk Empire in Turkish cities, where these pavilions were set up beside palaces and their yards. The functional purpose of these pavilions was being a rest area during journeys for princes and nobles and watching entertainment festivals and sporting events, as the pavilions were existed at the mountain tops and heights and took the shape of a square or rectangle section overlooking the outer space through arches. Pavilions/Kiosks were widespread during the Ottoman era in Turkey, where the Turkish palaces included kiosks/pavilions which were used for rest, watching celebrations, relaxation during night and enjoying the air breeze. 6.5. Turkish pavilions/kiosks during the Ottoman era were portrayed and drawn clearly in the Turkish manuscript paintings, especially pavilions/kiosks existed in Topkapi Palace due to its importance as it was the palace of Ottoman Sultans over many centuries. The large spaces of gardens and parks arouse the owners of these gardens either they are sultans, princes, nobles or traders to establish pavilions for enjoyment, relaxation and watching the social and cultural events, where the pavilion/kiosk become an architectural construction or a building annexed to palaces all over the world and through the ages.

6.6. Kiosks became common in Europe since the $15^{\text {th }}$ century in the Renaissance era, where the pavilions found in Europe which influenced by Islamic pavilions and Turkish kiosks as all of them resembled one another in terms of the general structure and functional purpose. The skillful architects and the factors of transferring the aspects or manifestations of art and the architectural effects from the Eastern countries into Germany posed an influential reason for transferring Germany from a first class industrial society into a society with an artistic and cultural background. This is due to the fact that Germany was influenced by free architecture thinking in addition to different cultures and civilizations especially those next to it either from artistic or technical aspects. 6.7. It is not possible to disregard the existence of two doors on the same axis in the small Garden Pavilion in the area of Herrenhausen known as ' Kleiner Gartenpavillon in Herrenhausen', as this architectural phenomenon or idea was found since the early Islamic ages. Examples of this phenomenon are represented in the Umayyad Mosque in Damascus-Syria 86 A.H/ 705 A.D, in addition to its existence in other Islamic buildings in Egypt that include but are not limited to AlAzhar Mosque 359 A.H/970A.D, Al-Hakim bi-Amr Allah Mosque 381 A.H/ 991 A.D, Al-Salih Tala'i Mosque 555 A.H/1160 A.D, the Abbasid Caliphs' Dome or so-called the Mausoleum of the 'Abbasid Caliphs 640 A.H/ 1242 A.D, Shajar Al-Durr Dome(Mausoleum)641A.H/1243A.D, and Al-Zahir Baybars Al-Bunduqdari Mosque 667A.H/1269A.D. Therefore, it can be said that the phenomenon of axial doors was common from Islamic times and was transferred to Europe.

6.8. It can be assumed and concluded that the pavilions continued to exist in Europe generally and in Germany especially, where they were influenced by Islamic civilization and other heritage cultures and as they were found in both traditional and modern forms, which were characterized by being completely built and overlooking the outer space through windows and doors, however they consisted of two floors similar to the traditional shape of kiosks or pavilions, this is like the pavilion of Hanover garden in Germany known as 'Gartenpavillon in Herrenhausen', which is followed the baroque style and was established in 1709 A.D, as well as the building founded under the name 'Privater Rokoko Garten Pavilion' dating back to the second half of the $18^{\text {th }}$ century in the city of Westfalia, western Germany.In addition to the pavilion of Göttingen garden known as 'Göttingen Gartenpavillon', which was established almost in 1807 A.D. The last three pavilions are discussed above and compared to other similar pavilions in the descriptive, applied, analytical and comparative study.

References 
Abd al-Wahhab, H. 1940 A. Al-'Asr al-Ayyubi, Majallat al-'Imara, Vol.2, Issue 7/8, pp.392-407.

Abd al-Wahhab, H. 1940 B. Asr al-Mamalik al-Bahriyya I, Majallat al-'Imara, Vol.2, Issue 9/10, pp. $468-480$.

Abdel-rahman, N. 2016. Egyptian Historical Parks, Authenticity vs. Change in Cairo's Cultural Landscape, Procedia - Social and Behavioral Sciences, Vol.225, pp.391-409.

Abdel-Razek, A. 2009. Islamic Architecture in Egypt "From the Arab Conquest to the End of the Mamluk Era", Dar Al-Fikr Al-Arabi, $1^{\text {st }}$ Ed., Cairo.

Abu-Lughod, J. 1965. Tale of two cities: the origins of modern Cairo, Comparative Studies in Society and History, Vol.7, pp. 429-457.

Acun, F. 2002. A Portrait of the Ottoman Cities, The Muslim World,Vol. 92,Issue 3/4,pp. 255285.

Agoston, G. 2009. Süleyman I, In: Agoston, G., and Bruce, M., (Eds.). Encyclopedia of the Ottoman Empire, Facts On File Press, New York, pp. 541-547.

Al-Bahnasi, A.1995. A Dictionary of Architecture and Art, Lebanon Publishing Library, $1^{\text {st }}$ Ed., Beirut-Lebanon.

Ali, M. 2012. Reviving the Character of Gardens of Heritage Value, M.A Thesis - Faculty of Engineering, Cairo University, Egypt.

Ali, N. 2012. Pottery Studies in Archeology and its Cognitive Diversity, Jordanian Journal of History and Archeology, Vol.6, Issue 3, pp. 124-138.

Alison, W. 1996. Britain's Royal Families: The Complete Genealogy, Revised edition, Random House Press, New York, pp.272-276.

Allchin, R., and Erdosy, G. 1995. The Archaeology of Early Historic South Asia: The Emergence of Cities and States, Cambridge University Press, Cambridge, pp. 257-259.

Alliot, M. 1946 . Le Rites de la chasse, Revue de l'Égypte ancienne, Vol.5, Paris, pp. 110-111.

Altintas, A. 2010. The World of Ottoman Guilds: The Issue of Monopoly, History Studies, Vol. 2, Issue 3, pp. 11-23. 
Ammalina, D. 2014. Impact of Ottoman Scientific Advancement in the Era of Sultan Muhammad al-Fatih (Mehmed the Conqueror) towards the Ottoman Scientific Zenith, Mediterranean Journal of Social Sciences, Vol.5, Issue 2, pp.81-86.

Andrew, H., and Shelley, G. 2011.Wrest Park, English Heritage Press, London.

Antram, N., and Morrice, R. 2008. Brighton and Hove, Pevsner Architectural Guides, Yale University Press, London.

Arnaudiès,A., Beaux,N., and Chéné, A. 2015.Une Chapelle de Sésostris Ier à Karnak,Soleb Press, Paris.

Artan, T. 2008. Questions of Ottoman Identity and Architectural History, In: Arnold, D. et al. (Eds.). Rethinking Architectural Historiography, Routledge Press, London, pp. 85-109.

Artan, T. 2010. Eighteenth -century Ottoman Princesses as Collectors: Chinese and European Porcelains in the Topkap1 Palace Museum, Ars Orientalis, Vol.39, pp.113-147.

Avcioğlu, N. 2003. A Palace of One's Own Stanislas I's kiosk and the Idea of selfrepresentation, the art Bulletin college art association, Vol. 85, Issue 4, pp. 662-684.

Avcioğlu, N. 2008. Istanbul: The Palimpsest City in Search of Its Architext, RES: Anthropology and Aesthetics,Vol.53,Issue 1,pp.190-210.

Barbara, M. 2000. Elbflorenz Italienische Präsenz in Dresden 16-19 Jahrhundert, Verlag der Kunst, München.

Barbara, M. 2005. Kunst und Repräsentation am Dresdner Hof, Deutscher Kunstverlag, München.

Barguet, P. 1962. Le Temple d'Amon-Rê à Karnak, Impr. de l'Institut Français d'archéologie Orientale, Le Caire.

Baykal, K.1982.Bursa ve anitlari,Türkiye Anit-Çevre Turizm Degerlerini Koruma Vakfi, Turkey.

Bechter, B. 2007. Der Brühlsche Garten in Dresden- Friedrichstadt, In: Die Zeitschrift Die Gartenkunst/ Die Gartenkunst,Vol.19,Issue 1,pp.1-46.

Bloom, J.1982.The Mosque of Baybars al-Bunduqdari in Cairo, Annales Islamologiques, Vol.18, pp.45-78. 
Bloom, J. 1983.The Mosque of al-Ḥākim in Cairo, Muqarnas, Vol. 1, pp.15-36.

Boyle, J. 1978A. Khāḳān, In: van Donzel, E., Lewis, B., Pellat, Ch., and Bosworth, C. E. (Eds.).The Encyclopaedia of Islam, New Edition, Vol. IV, E. J. Brill Press, Leiden.

Boyle, J.1978B. Khān, In: van Donzel, E., Lewis, B., Pellat, Ch., and Bosworth, C. E. (Eds.). The Encyclopaedia of Islam, New Edition, Vol. IV, E. J. Brill Press,Leiden.

Breasted, J.H. 1907. Ancient Records of Egypt: Historical Documents from the Earliest Times to the Persian Conquest, The University of Chicago Press, Chicago.

Brett, M. 2001. The Rise of the Fatimids: The World of the Mediterranean and the Middle East in the Fourth Century of the Hijra, Tenth Century CE, The Medieval Mediterranean, Vol.30, Brill Press, Leiden, pp.1-35.

Bünermann, M.1970. Die Gemeinden des ersten Neugliederung programms in NordrheinWestfalen, Deutscher Gemeindeverlag, Köln.

Burns, R. 2005. Damascus: A History, Routledge Press, London.

Canard, M.1965. Fatimids, In: Lewis, B., Pellat, Ch., and Schacht, J. (Eds.). The Encyclopaedia of Islam, New Edition, Vol. II, E. J. Brill Press, Leiden, pp. 850-862.

Carlotti, J.F.1995. Mise au Point sur les dimensions et la localisation de la chapelle d'Hatshepsout à Karnak, Cahiers de Karnak, Vol. 10, pp.141-166.

Caroline, F. 2005. Osman's Dream: The Story of the Ottoman Empire, 1300-1923, Basic Books Press, New York.

Chevrier, H.1928. Rapport sur les travaux de Karnak (1927-1928), Annales du service des antiquités de l'Égypte, Vol.28,Le Caire, pp.114- 128.

Chevrier, H.1938. Rapport sur les travaux de Karnak (1937-1938), Annales du service des antiquités de l'Égypte, Vol.38, Le Caire, pp.567-608.

Chevrier, H.1955. Rapport sur les travaux de Karnak, 1953-1954, Annales du service des antiquités de l'Égypte, Vol.53, pp.21-42.

Christian, L., and Songül, M. (Eds.). 2012. Seljuqs: Politics, Society and Culture Edinburgh University Press, United Kingdom, pp.1-328. 
Cornelissen,G. 1986. Das Niederländische im preußischen Gelderland und seine Ablösung durch das Deutsche, Rohrscheid, Bonn.

Cortese, D.2014. Fatimids in Muhammad in History, Thought, and Culture, In: Fitzpatrick,C., and Walker, A.,(Eds.). Encyclopedia of the Prophet of God, Vol.I, ABC-CLIO Press, Santa Barbara, pp.187-191.

Creswell, K.A.1952. The Muslim Architecture of Egypt I, Ikhshids and Fatimids, A.D. 9391171, Clarendon Press, Oxford.

Creswell,K.A. 1978. The Muslim Architecture of Egypt, 2 Vols., Hacker Art Books Press,New York.

D'hulster, U.K, and Steenbergen, J.V. 2013. Egypt and Syria in the Fatimid, Ayyubid and Mamluk Eras, Uitgeveri J peeters en department Oosterse Studies, Paris, pp.75- 86.

Darwish, E. 2002.The art of Pottery,Damascus House for Printing and Publishing, $1^{\text {st }}$ Edition, Syria.

Darwish, M. 2019. The architectural heritage of the Fatimid and Ayyubid in Egypt, Foundation of Nation Sciences for Cultural Investments Press, Cairo.

Delchevalerie, G. 1897. Le Parc Public de l'Ezbekieh au Caire, C. Annoot-Braeckman Publisher, Paris.

Demiralp, Y. 1999. Erken Osmanlı Sanat1, Beyliklerin Miras1, Early Ottoman Art: The Legacy of the Emirates, Madrid, pp.108-111.

Doris, B. 1985. Azbakiyya and its Environments from Azbak to Ismail (1476-1879), Cairo.

Doris, B. 1989A. Islamic Architecture in Cairo, E. J. Brill Press, Leiden.

Doris, B. 1989B. The Mosque of Caliph al-Hākim bi Amr Allāh (990-1003, Islamic Architecture in Cairo: An Introduction, Brill Press, Leiden.

Doris, B. 2007. Cairo of the Mamluks: A History of the Architecture and its Culture, I.B. Tauris and Co. Ltd. Press, London. 
Dostoglu,N., Kitagawa,K., and Asami, Y. 2004. Locational Tendency of Mosques in Bursa, Turkey: Regional Study Using Geographic Information System, Journal of Architectural and Planning Research, Vol. 21, Issue 3, pp. 209-221.

Dostoglu,N., and Vural,T. 2002. The Role of Western Planners in the Transformation of Bursa from a Traditional Ottoman City to a Metropolitan Center of the Turkish Republic, In: Turgut, H., and Kellett, P., (Eds.). Traditional Environments in a New Millenium: Second International Symposium of IAPS-CSBE Network; İstanbul, pp. 239-245.

El Ashmouni, M., and Bartsch, K. 2014. Egypt's Age of Transition: Unintentional Cosmopolitanism during the Reign of Muhammad'Alī (1805-1848), Arab Studies Quarterly, Vol.36, Issue 1, pp.43-74.

El Kadi,G. 2012. Cairo a Centre in Movement, IRD Éditions, Institut de recherche pour le développement, Marseille.

El Messiri, N. 2004. A Changing Perception of Public Gardens, In: Bianca,S., and Jodidio, P., (Eds.). Cairo: Revitalising a Historic Metropolis, Umberto Allemandi, Turin, pp.221-233.

El-Ghobashy, S., and Mosaad, G. 2016. Nature Influences on Architecture Interior Designs, Procedia Environmental Sciences, Vol. 34, pp.573-581.

Elizabeth, B. 2006. Karnak Evolution of a temple, Routledge Press, London.

Engelbrecht, M. 2017. Landschaftsgärtner mit den Werkzeugen und Geräten seiner Zeit um 1721, Deutsche Verlags - Anstalt, München.

Ezad, A., Ammalina, D., and Mohamad, A. 2014. Sultan Muhammad al-Fatih: Ottoman's Great Strategic Planner, Middle-East Journal of Scientific Research, Vol.20, Issue 12, pp.2158-2163.

Fahmy, K. 2002. An olfactory Tale of Two Cities: Cairo in the Nineteenth Century, In: Edwards, J. (Ed.). Historians in Cairo: Essays in Honour of George Scanlon, Cairo, pp.155-187.

Fiedler, A. 1904. Zur Geschichte Des Kurländischen Palais und des Marcolinisehen Palais, Dresden, Germany.

Freely, J. 2011. A History of Ottoman Architecture, WIT Press, UK.

Gabriel, A.1958. Une capitale turque, Brousse-Bursa, E. de Boccard Press, Paris.

Gökbilgin, T. 1991. Edirne, Encyclopaedia of Islam, Vol.2, 2 ${ }^{\text {nd }}$ Ed., Brill Press, Leiden. 
Goodwin, G. 1997. A History of Ottoman architecture, Johns Hopkins Press, Baltimore.

Grafman, R., and Rosen-Ayalon, M. 1999. The Two Great Syrian Umayyad Mosques: Jerusalem and Damascus, Muqarnas,Vol.16, Brill, Boston, pp.1-15.

Graindorge, C. 1993. Naissance d'une chapelle reposoir de barque, Les Dossiers d'Archaeologie, Vol. 187, pp. 42-53.

Grassart-Bleses, A. 2017. Les Représentations des Déesses dans le programme décoratif de la chapelle rouge d'Hatchepsout à Karnak: le rôle particulier d'Amonet,Karnak,Vol.16,pp.253-268.

Griffith, R. 1911. Grille, In: Chisholm, H. (Ed.). Encyclopædia Britannica, $11^{\text {th }}$ Ed., Vol.12, Cambridge University Press, Cambridge.

Grousset, R. 1991. The Empire of the Steppes, Rutgers University Press, New Jersey.

Gupta, R., and Limkatanyoo, P. 2008. Practical Approach to designing wood roof truss assemblies, practice periodical on structural design and construction,Vol. 13, No.3, pp.135-146.

Halil, E.A. 2009. Istanbul City Guide, A.S Book Press, Turkey.

Halil, I., and Suraiya, F. 1997. An Economic and Social History of the Ottoman Empire, Vol.I, Cambridge University Press, Cambridge.

Harris, J. 2014. Byzantium and the Crusades, Bloomsbury Publishing, London.

Harris, T. 2012. The German Garden City movement "Architecture, Politics and Urban transformation"1902-1931, Ph.D Thesis, Colombia University, New York.

Hasan, D. 2008A. REVAN KÖŞKÜ, In: Türkiye Diyanet Vakfı İslâm Ansiklopedisi, Vol.35, Turkey, pp.29-30.

Hasan, D. 2008B. REVAN KÖŞKÜ, TDV İslâm Ansiklopedisi, https://islamansiklopedisi.org.tr/ revan-kosku (18.01.2020).

Hathaway, J. 2013. The Arab Lands under Ottoman Rule: 1516-1800, Routledge Press, London.

Heinrichs,F. 1996. Die Wurzeln des Städte- und Gemeindebundes - 25 Jahre NW Städte- und Gemeindebund, In: Heinrichs,W.F., (Ed.). Städte- und Gemeinderat, Vol.5,pp.156-162. 
Henning, W. 1952. A Farewell to the Khagan of the Aq-Aqataran, Bulletin of the School of Oriental and African studies, the University of London, Vol. 14, Issue 3, pp. 501-522.

Henry, A., and Stewart, J., (Eds.). 2011. Practical building conservation; Mortars, Plasters and Renders, Ashgate Publishing, Farnham, UK.

Hoffmann,H.C. 2010. Göttingen Sachbücher lag Karin Mader, Germany.

Howard, D. 1988. Ottoman Historiography and the Literature of Decline of the Sixteenth and Seventeenth Centuries, Journal of Asian History, Vol.22, pp.52-77.

Hussein, M. 2010. Islamic Ceramics in Egypt, Dar Gharib for Printing and Publishing, $1^{\text {st }}$ Ed., Cairo.

Hvinden-Haug, L. 2016. Turkish Influence in European Architecture - the Tea-House at Eleja in Latvia, Norwegian Institute for Cultural Heritage Research (NIKU), pp.1-3.

Imran, S., Selen, D., and Tülin, A. 2019. Following Traces of a public open space from $14^{\text {th }}$ Century: Bursa Orhan Gazi Square In Turkey, European Journal of Sustainable Development, Vol.8, Issue 1, pp.237-263.

Jackson-Stops, G. 1991. Views of the Royal Pavilion, Abbeville Press, New York.

Janelis, M. 2010. Manor Gardens and Parks of Latvia, Neputns Press, Latvia.

Jirn, Kh. 2005. Guide to Gardens Engineering, The National Library Press, The Hashemite Kingdom of Jordan.

Kamil, J. 1996. The Ancient Egyptians: Life in the Old Kingdom, AUC Press, Cairo.

Keskiner, P. 2012. Sultan Ahmed III (r. 1703-1730) as a calligrapher and patron of calligraphy, Ph.D Thesis, The University of London.

King, J.R. 1984.The Restoration of the Al-Hākim Mosque in Cairo,Islamic Studies, Vol.23, Issue 4, pp. 325-335.

Krabbenhöft, N. 2011. A Veneer of Power, Thirteenth century Seljuk frescoes on the walls of Alanya and some Recommendations for their preservation, Koc University, Istanbul- Turkey.

Krader, L. 1955. Qan-Qayan and the Beginnings of Mongol Kingship, Central Asiatic Journal, Vol. 1, Issue 1, pp.17-35. 
Krahl, R. 1986. Export Porcelain Fit for the Chinese Emperor, Early Chinese Blue-and-White in the Topkapî Saray Museum, Istanbul, Journal of the Royal Asiatic Society of Great Britain and Ireland,Vol.1, pp.68-92.

Kuban, D. 1996. Istanbul, An Urban History, Istanbul, The Economic and Social History Foundation of Turkey, Turkey.

Kuehn, S. 2011. The Dragon in Medieval East Christian and Islamic Art, Islamic History and Civilization, Vol.86, Brill Publishers, Leiden, pp.166-180.

Kunt, M. 2006. The later Ottoman Empire 1603-1839, In: Faroqhi, S.N., (Ed.). The Cambridge History of Turkey, Vol. 3, Cambridge University Press, Cambridge.

Kuran, A. 1987. Sinan, The Grand Old Master of Ottoman Architecture, Ada Press, Washington DC and Istanbul.

Kurtaran, U. 2013. Sultan Mahmud Period (1730-1754) Reform Movements, Turkish StudiesInternational Periodical For The Languages, Literature and History of Turkish or Turkic, Vol.8, Issue 2, pp. 167-179.

Lacau, P., and Chevrier,H. 1956. Chapelle de Sésostris Ier à Karnak, Le Caire.

Lacau, P., and Chevrier, H. 1977. Une Chapelle d' Hatshepsout à Karnak, Vol.I, Le Caire.

Lamar,G. 2000. Jerome Bonaparte: The War Years1800-1815, Greenwood Press, Connecticut/ USA.

Larché, F., and Franck, B. 2006. La Chapelle Rouge: le sanctuaire de barque d'Hatshepsout/1: Fac-similés et photographies des scènes, Recherche sur les civilisations, Paris.

Lev, Y. 1987. Army, Regime, and Society in Fatimid Egypt, 358-487/968-1094, International Journal of Middle East Studies, Vol.19, Issue3, pp.337-365.

Levy, M. (Ed.). 2012. Göttingen, In: Encyclopædia Britannica, Encyclopædia Britannica, Inc. Publisher/ https://www.britannica.com/place/Gottingen (accessed date 18/12/2019).

Lillian, M.L. 2012. The Garden of perfect brightness - the European Palaces and Pavillions of the Yuanmingyuan, Massachusetts Institute of Technology, Visualizing Cultures, pp. 1-26. 
Limper-Herz, K. 2013. Homes and Gardens: Architecture in Georgians Revealed: Life, Style and the Making of Modern Britain, published in the British Library and Paul Mellon Centre for Studies in British Art, London, pp.26-33.

Limper-Herz, K. 2019. Humphry Repton and John Nash, published in Transforming Topography, the British Library and Paul Mellon Centre for Studies in British Art. This article is an edited version of Karen Limper-Herz chapter 'Homes and Gardens: Architecture' in Georgians Revealed: Life, Style and the Making of Modern Britain, The British Library Press, London, 2013, pp.26-33.

Mackay-Quynn, D. 1956. Jerome Bonaparte in Antilles1801-1803, Revue de 1'Institut Napoleon, Vol.60, pp.81-95.

Malins, E. 1980. Indian Influences on English Houses and Gardens at the Beginning of the Nineteenth Century, Garden History, Vol. 8, Issue 1, pp. 46-66.

Marriet, A. 1875. Karnak, étude topographique et archéologique, Leipzig.

Mestyan,A.2013.Power and music in Cairo:Azbakiyya,Urban History,Vol.40,Issue4,pp.681-704.

Micklewright, N. 2017. A Victorian Traveler in the Middle East: The Photography and Travel Writing of Annie Lady Brassey, Routledge Press, London.

Murnane,W.1967.The Sed Festival:A Problem in Historical Method,MDAIK,Vol.37,pp.369-376.

Muthesius, H. 1994. Style-Architecture and Building-Art, Transformations of architecture in the Nineteenth Century and its Present Condition, translated by: Stanford Anderson, Getty Center for the History of Art and Humanities, U.S.A.

Myer, R. 1961. Images and Influences of Oriental Art: A Study in European Taste, Art Journal, Vol. 20, Issue 4, pp. 203-210.

Necipoğlu, G. 1991. Architecture, Ceremonial, and Power: The Topkap1 Palace in the Fifteenth and Sixteenth Centuries, MIT Press, Cambridge.

Necipoğlu, G. 2007. Creation of a national genius: Sinan and the Historiography of Classical Ottoman architecture, Muqarnas, Vol. 24, pp.141-183.

Niebaum, H., and Mache,J. 2011.Einführung in die Dialektologie des Deutschen, Germanistische Arbeitshefte, Vol. 37, De Gruyter Press, Berlin. 
O'Kane, B. 1993. From tents to pavilions: royal mobility and Persian palace design, Ars Orientalis, Vol.23, pp.249-268.

O'Kane, B. 2012. The Illustrated Guide to the Museum of Islamic Art in Cairo, AUC Press, Cairo.

Ongan, A. 1940. yılında Türk Tarih Kurumu tarafından yapılanTopkapı Sarayı hafriyatı; (The Excavations in Topkapı Palace conducted by the Turkish Historical Society in 1937), Belleten, Vol. IV, pp. 318-355.

Ozaslan , N., and Akalin, A. 2011. Architecture and Image, the example of Turkey, Middle Eastern studies, Vol. 47, No. 6, pp. 911- 922.

Parry, J. 1976. The Reigns of Bayezid II and Selim I, 1481-1520, A History of the Ottoman Empire to 1730, In: Cook, M., (Ed.).The Cambridge History of Islam and The New Cambridge Modern History, Cambridge, pp.54-78.

Peacock, A. 2015. Great Seljuk Empire, Edinburgh University Press, UK.

Peters, L. 2009. Rokoko - Pavilion in Kaldenkirchen, Rundgang Historisches Kaldenkirchen, Festungkaldenkirchen um 1650, Toni Peters druck Gmbh. Co.KG., Germany.

Pillet, M. 1923. Le Naos de Senousert Ier, Annales du service des antiquités de l'Égypte, Vol. 23, pp.143- 158.

Pillet, M. 1924. Rapport sur les travaux de Karnak (1923-1924), Annales du service des antiquités de l'Égypte, Vol.24, pp.53-88.

Porter, B., and Moss, R. 1972. Topographical Bibliography of Ancient Egyptian Hieroglyphic Texts, Reliefs and Paintings, Vol.2, Oxford.

Pradines, S., and Rahmat, K. 2016. Fatimid Gardens archaeological and Historical Perspectives, Bulletin of SOAS, the University of London Press, pp.1-30.

Rabbat,N. 1996. Al-Azhar Mosque: An Architectural Chronicle of Cairo's History, In: Necipogulu, G., (Ed.). Muqarnas- An Annual on the Visual Culture of the Islamic World, Vol.13, Brill, pp. 45-67.

Rabbat, N. 2003. Who was al-Maqrizi? A Biographical Sketch, Mamluk Studies Review, Vol.VII, Issue 2, Middle East Documentation Center, The University of Chicago Press, pp.1-19. 
Rawas, A. Q. 1991. An Introduction to Islamic Aesthetics, Qutaiba House for Printing, Publishing and Distribution, $1^{\text {st }}$ Edition, Damascus.

Refai, A.,(Ed.). 2009. Muhammad Ali Pavilion at Shubra, In: The Heritage of Egypt, The History, Archaeology and Legacy of Egypt,Vol.2,No.3,Issue 6, Al-Hadara Publishing Press, Cairo, Egypt, pp.2-4.

Roemer, H. R. 1986. The Safavid Period; The Cambridge History of Iran: The Timurid and Safavid Periods, Vol.VI, Cambridge University Press, Cambridge.

Ruggles, D. 2015. Visible and Invisible Bodies: The Architectural Patronage of Shajar Al-Durr, Muqarnas, Vol.32, Issue 1, pp. 63-78.

Sakaoğlu, N. 2015. Bu Mülkün Sultanları, Alfa Yayıncılık Press, Istanbul.

Salama, F. 2013. The Role of Planning in Influencing Community Welfare through public spaces as an entry to study Residential Neighborhood Gardens, M.A Thesis, Faculty of Engineering, Ain Shams University, Egypt.

Sanders, P. 1994. Ritual, Politics and the City in Fatimid Cairo, New York.

Saoud, R. 2003. Muslim Architecture under Seljuk Patronage (1038-1327). Foundation for Science, Technology, and Civilization, Vol.4041, pp. 1-13.

Schwarting,G. 2005. Der Deutsche Städtetag wird 100 - die organisierte Interessenvertretung der Kommunen im 20. Jahrhundert, DÖV, Vol.58, pp.458-465.

Semavi, E. 1991A. BAĞDAT KÖŞKÜ, TDV İslâm Ansiklopedisi, https://islamansiklopedisi.org.tr/bagdat-kosku (18.01.2020).

Semavi, E. 1991B. BAĞDAT KÖŞKÜ, Türkiye Diyanet Vakfı İslâm Ansiklopedisi, Vol. 4, Turkey, pp. 444-446.

Shama, N. et al. 2014. Evaluation of the Service, Environmental and Aesthetic Dimensions of the Public Garden in the New Sham Suburb, Journal of Damascus University for Agricultural Sciences, Vol. 30, Issue 1, pp.9-28.

Shaw, I. 2003. Exploring Ancient Egypt, Oxford University Press, Oxford.

Sim, J. 2015. Planting Design Sourcebook, Queensland University of Technology, pp.5-18. 
Skowski, J. 2013. Heimat finden durch Interkulture de Gärten, Informationen zur Raumentwicklung, Vol. 5, Bundes Institut für Bau Stadt und Raumforschung,Bonn,pp.421-425.

Soltanzadeh, H., and Hassanpour, N. 2015. How Traditional Ottoman Houses affect contemporary architecture in Turkey, the scientific journal of Nazar research center for ArtArchitecture- Urbanism, Vol. 12, No. 36, pp. 47- 60.

Staveteig, K.R. 2007. Historic Decorative Metal Ceilings and Walls "Use, Repair and Replacement", National Park Service, U.S. Department of the Interior, Technical Preservation Services, pp. 1-19.

Sukopp, H. 2003. Flora and Vegetation Reflecting the Urban History of Berlin, Regionaler Beiträg, Die erde 134, pp. 295-316.

Sullivan, E. 2010. Karnak: Development of the Temple of Amun-Ra, In: Willeke, W., (Ed.). UCLA Encyclopedia of Egyptology, Los Angeles,pp.1-34.

Summerson, J. 1993. Architecture in Britain, 1530-1830, $9^{\text {th }}$ Rev. Ed., Yale University Press, Pelican History of Art Series, USA.

Summerson, J. 2003. Georgian London, the Paul Mellon Centre for Studies in British Art, Yale University Press, USA.

Szücs, L., and Jaszczak, A. 2013. Landscape values and functional changes of suburban areas A case study of Göttingen (Germany), Acta Sci. Pol.,Administratio Locorum,Vol.12, Issue 2, pp. 89-100.

Szuggat, S. 2012. Historische Friedrichstadt, Städtische Vielfalt in Bewegung, Stadtplanungsamt Press, Dresden, Germany.

Taylor, P. 2008. Gardens of Britain and Ireland, Dorling Kindersley Ltd. Press, London.

Todorov, N. P. 2012. The Napoleonic Administrative System in the Kingdom of Westphalia, In: Broers, M., Hicks, P., and Guimera, A., (Eds.). The Napoleonic Empire and the New European Political Culture, Palgrave Macmillan, UK.

Toledano, E. 1985. Mehmet Ali Paşa or Muhammad Ali Basha?An historiographic appraisal in the wake of a recent book, Middle Eastern Studies, Vol.21, Issue 4, pp.141-159.

Ulusoy, M., and Kuyrukcu, E. 2012. The meaning and importance of the traditional architecture, Procedia - Social and Behavioral Sciences, Vol. 47, pp. 2120-2126. 
Van Siclen, Ch. 1989. New Data on the Date of the Defacement of Hatshepsut's name and Image on the Chapelle rouge, Göttinger Miszellen: Beiträge zur äegyptologischen Diskussion, Vol.107, pp.85-86.

Vera, A. 1912. Le Nouveau Jardin, Emile Paul Press, Paris.

Volait, M. 2003. Making Cairo Modern (1870-1950): Multiple Models for "European-style" Urbanism, In: Nasr,J., and Volait,M., (Eds.). Urbanism - Imported or Exported ? Native Aspirations and Foreign Plans/ Wiley-Academy Press, England, pp.17-50.

Wadsworth, E. 1924. Stucco Reliefs of the First and Second Centuries still Extant in Rome, Memoirs of the American Academy in Rome, Vol.4, Rome.

Wagner, C. 2017. Tag des Offenen Denkmals Macht und Pracht, Historischer Rundgang, Nettetal - Kaldenkirchen, Nettetal, Germany.

Wagner, O. 1988. Modern Architecture, Published by the Getty Center for the History of Art and the Humanities, USA.

Walker, P. 2002. Exploring an Islamic Empire: Fatimid History and its Sources,I.B.Tauris Press, London.

Wasti, T. 2004. The 1912-13 Balkan Wars and the Siege of Edirne, Middle Eastern Studies, Vol. 40, Issue 4, Taylor \& Francis, Ltd. Press, pp. 59-78.

Wienerberger Building Solutions, Clay roof tile designed for living- Wienerberger Building Material Solutions, on:https://www.wienerberger-building-solutions.com/About/ WienerbergerBuilding-Solutions.html\# (Accessed date 17/11/2019).

Wilkinson, R.H. 1992. Reading Egyptian Art: A Hieroglyphic Guide to Ancient Egyptian Painting and Sculpture, Thames and Hudson Press, USA.

Wilkinson, T. 1999. Early Dynastic Egypt, Routledge Press, London.

Williams, C. 2008. Islamic Monuments in Cairo: The Practical Guide, $6^{\text {th }}$ Ed., AUC Press, Cairo.

Wilson, D.A., et al. 2004. Planning and Designing your Home Landscape, University of Wisconsin, Extension publishing, Madison, U.S.A. 
Wilson,J. 1989. Designing the Roman Corinthian Order, Journal of Roman Archaeology,Vol.2, pp.35-69.

Winkler, B., and Maier, A. 2019. Lewandowski (I): Urban Gardening in Germany "Cultivating a sustainable lifestyle for the Societal", transition to a bio economy, Vol. II, Basel- Switzerland.

Woldemar, H., Eckhart, S., and Michael, S., (Eds.). 2006. Tagebuch meines Wirkungskreises in der Architektur.Hermanns Bautagebuch von 1826 bis 1847,Verlag Notschriften Press, Radebeul, Germany.

Wolfgang, M. 1988. Das Kavak Sarayı Ein verlorenes Baudenkmal Istanbuls, Istanbuler Mitteilungen, Vol.38, pp. 363-376.

Woodside, A. 2002. The Ch'ien-Lung Reign, In: Peterson, W. J., (Ed.). The Cambridge History of China, Cambridge University Press, Cambridge.

Yeomans,R. 2006. The art and architecture of Islamic Cairo,Garnet publishing, $1^{\text {st }}$ Ed., Lebanon.

Yuksek, I., and Esin, T. 2010. Assessment of Energy efficiency of Kırklareli Traditional Houses, Plumbing Engineering Journal, Vol.117, pp.32-40.

Yuksek, I. 2013. Design of Building Elements in Traditional Houses, Gazi University Journal of Science, Part B: Art, Humanities, Design And Planning, Vol.1, Issue 4, pp.57-67.

Zessin, S. 2015. Herrenhäuser Gärten: Großer Garten/Herrenhausen Gardens:Great Graden, Verlag Eugen Ulmer Press, Germany.

Zhao, G. 2006. Reinventing China Imperial Qing Ideology and the Rise of Modern Chinese National Identity in the Early Twentieth Century, Modern China, Vol.32, Issue 1, pp. 3-30.

Zumpe, M. 1991. Die Brühlsche Terrasse in Dresden, Verlag für Bauwesen GmbH, Berlin. 